\title{
Multi-Temporal Evaluation of Landslide Movements and Impacts on Buildings in San Fratello (Italy) By Means of C-Band and X-Band PSI Data
}

\author{
Silvia Bianchini, ${ }^{1}$ Andrea Ciampalini, ${ }^{1}$ Federico Raspini, ${ }^{1}$ Federica Bardi, ${ }^{1}$ Federico Di Traglia, ${ }^{1,2}$ \\ SANDro Moretti, ${ }^{1}$ and Nicola Casagli ${ }^{1}$
}

\begin{abstract}
This work provides a multi-temporal and spatial investigation of landslide effects in the San Fratello area (Messina province within the Sicily region, Italy), by means of C-band and X-band Persistent Scatterer Interferometry (PSI) data, integrated with in situ field checks and a crack pattern survey. The Sicily region is extensively affected by hydrogeological hazards since several landslides regularly involved local areas across time. In particular, intense and catastrophic landslide phenomena have recently occurred in the San Fratello area; the last event took place in February 2010, causing large economic damage. Thus, the need for an accurate ground motions and impacts mapping and monitoring turns out to be significantly effective, in order to better identify active unstable areas and to help proper risk-mitigation measures planning. The combined use of historical and recent C-band satellites and current X-band Synthetic Aperture Radar sensors of a new generation permits spatially and temporally detection of landslide-induced motions on a local scale and to properly provide a complete multi-temporal evaluation of their effects on the area of interest. PSI ground motion rates are crosscompared with local failures and damage of involved buildings, recently recognized by in situ observations. As a result, the analysis of landslide-induced movements over almost 20 years and the validation of radar data with manufactured crack patterns, permits one to finally achieve a complete and reliable assessment in the San Fratello test site.
\end{abstract}

Key words: Synthetic Aperture Radar, Persistent Scatterer Interferometry, field survey, landslides, San Fratello.

\section{Introduction}

The occurrence of landslides in populated areas can pose a serious threat to human lives, property and structures. Moreover, where significant cultural

\footnotetext{
1 Department of Earth Sciences, University of Firenze, Via G. La Pira 4, 50121 Florence, Italy. E-mail: silvia.bianchini@unifi.it

2 Department of Earth Sciences, University of Pisa, Via Santa Maria 53, 50126 Pisa, Italy.
}

heritage is present, the socio-economic losses and damages are stronger because of the higher value of the elements at risk.

The detection of active ground movements on unstable slopes and landslide-prone areas can greatly benefit from advanced remote sensing techniques, i.e,. Persistent Scatterer Interferometry (PSI), thanks to their non-invasiveness, availability and high precision (FerRetti et al. 2001). Furthermore, radar satellite data analysis and traditional geomorphological tools, like field surveys and in situ observations are complementary for the mapping and monitoring of the impacts of such natural phenomena on buildings and manufactures of affected areas.

Persistent Scatterer Interferometry throughout the use of medium resolution Synthetic Aperture Radar (SAR) data in C-band (e.g., from ERS/ENVISAT satellites) has been demonstrated to be a valuable tool for back-monitoring slow-moving landslides, with good accuracy (up to $1 \mathrm{~mm} /$ year) and maximum detectable movement of about 15-20 cm/year (HANSSEN 2005; Ferretti et al. 2005; AdAm et al. 2008; CASCini et al. 2010; Cigna et al. 2013).

The launch of new SAR sensors that operate at $3 \mathrm{~cm}$ wavelength in X-band, i.e., TerraSAR-X and COSMO-SkyMed, with higher spatial resolution and reduced revisiting time (4-16 days) compared to the previous C-band satellites, has enhanced PSI capability for landslides detection and monitoring, allowing the identification of more recent and faster ground movements affecting small areas with improved precision. X-band SAR images make the number of retrieved PS targets higher by a factor of approximately 100-200, compared to medium resolution data (Cuevas et al. 2011). Most of the PS 
targets show up on housetops and especially on facades and roofs of buildings, enabling a site-specific investigation. Therefore, the use of X-band data significantly improves the level of detail of the analysis, since small structures now act as stable scatterers and PS from different surfaces can be separated due to the very high resolution of up to $1 \mathrm{~m}$ in azimuth and range direction (Rотн et al. 2003; GE et al. 2010; Gernhardt et al. 2010; NotTi et al. 2010).

C-band satellites provide the availability of long historical archives of motion rates and time series, covering wide areas at a relatively low cost and medium spatial resolution. On the other hand, X-band data, with higher spatial and temporal resolution, allow for a more detailed investigation even at the scale of a single building movement, in a recent and shorter span of time (e.g., some months) (CROSETTO et al. 2010; Tomás 2010; Bovenga et al. 2012; BRU et al. 2013).

Radar data can provide an initial and non-invasive evaluation of most critical unstable areas, to be performed "at desk", prior to in situ survey. Thus, PSI data give a preliminary and rapid discrimination of the most unstable slopes over wide areas and, consequently, need to be integrated with additional geoinformation and auxiliary data to obtain a more robust interpretation at a local scale. A detailed structural damage analysis of several buildings is required for cross-comparing crack pattern survey with PSI motion rates, for achieving a complete investigation (HERRERA et al. 2010).

The Sicily region of Italy is extensively affected by hydrogeological hazards, and several landslides occurred at localized areas across time, causing casualties and large economic damage (ARDIZzONE et al. 2012; CiAmpalini et al. 2012; Cigna et al. 2012). In particular, intense and catastrophic landslides have recently occurred in the San Fratello area. The recent activity coupled with the historical significance of many of the affected structures, field observations of damage, and the availability of SAR data make this an ideal field site.

In this paper the impacts of landslides in San Fratello are investigated from 1992 to 2012 by combining the available C-band and X-band SAR data along with a field survey of structural damages.
Multi-temporal estimation of radar velocities and related impacts on cultural and social heritage lead to an assessment of ground movements and landslide damage occurring within San Fratello over 20 years.

\section{Study Area}

\subsection{Geographical and Geological Setting}

San Fratello village is located in the NE sector of the Sicily Region (Southern Italy), within Messina province, at $640 \mathrm{~m}$ a.s.l. on the Nebrodi Mountains, which, together with the Peloritani Mountains, represent part of the Apenninic-Maghrebian orogenic chain (Cubito et al. 2005) (Fig. 1).

This area is made up of imbricate sheets of Mesozoic-Tertiary rocks, made of the lowermost autochthonous African foreland units, overlapped by the Appenninic-Maghrebian sequences (CORRADO et al. 2009). These Appenninic units are tectonically overthrusted by allochthonous Kabilo-Calabrian Units, which represent different tectonic assemblages derived from the European continental margin (according to OGniben 1969; KNott 1987; Dietrich 1988) or, according to an opposite interpretation, to an Eo-Alpine chain (Austroalpine sector) piled up toward the European foreland (AMODIO-MoRelli et al. 1976). Overall, the tectonic nappes are E-SE verging and show a total thickness of about $15 \mathrm{~km}$.

The rocks outcropping in the area consist of a sequence of terrigenous to calcareous sedimentary sequences belonging to the different already mentioned paleogeographic domains (Fig. 1). The western and southern part of the study area are mostly characterized by terrigenous terrains, since the lower Cretaceous clayey sequences-called the Argille Scagliose Unit - extensively crop out (AppeninicMaghrebid Units). In the northern portion of the area, the top units (Kabilo-Calabride Units) made of predominantly carbonate complexes outcrop, represented by Liassic limestone platform sequences, overlapped by a terrigenous Late Eocene-Oligocene Flysch (Frazzanò Flysch). The uppermost Cretaceous pelagic dolostones and limestones close the tectonic sequence (San Marco D'Alunzio Unit), outcropping towards N-NW San Fratello village (NIGRO and SulLI 1995; LAVECCHIA et al. 2007). 

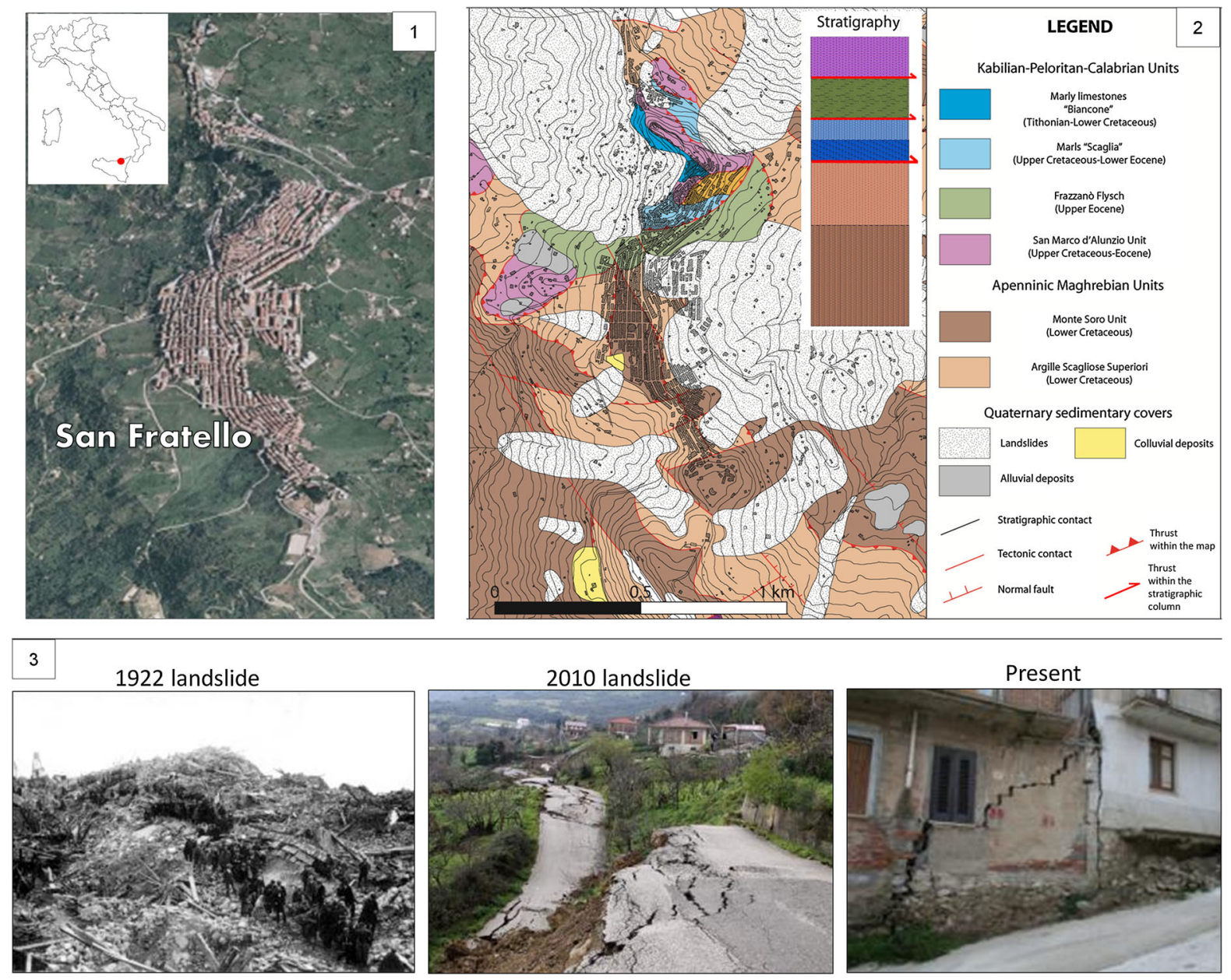

Figure 1

Study area: 1 Geographical location of San Fratello village (Messina province) in South Italy; 2 geological map and stratigraphic sequence; 3 photos referred to the most recent recorded landslides and present scenario

Throughout the inhabited area, an aquifer is also present, at a depth of between 0.5 and $2.5 \mathrm{~m}$ from the surface ground level (D.R.P.C. 2010).

From a geomorphological point of view, the test site is strongly influenced by the geo-structural conditions and the recent tectonic activity. The landscape is typical of recently uplifted areas: steep slopes, narrow valleys, high topographical gradient and remarkable relief energy are the most impressive geomorphological features of the study area. Moreover, all the geological units are highly tectonized, being these clays highly fissured and the stone-like lithotypes extensively fractured.

\section{Landslides Occurrence}

Messina province is prone to landslide hazard, mainly due to the steep topography, the nature of the lithotypes, mainly consisting of flysch units with tectonized silt-clay levels, and the occurrence of intense and seasonally high rainfall events (Mondini et al. 2011; Del VentisetTe et al. 2012; RASPINI et al. 2013).

The main landslide types can be prevalently classified as debris flows, complex slides (VARNES 1978) and shallow and deep-seated landslides.

San Fratello has been chronically affected by landslides (Fig. 1). A severe landslide event dates 

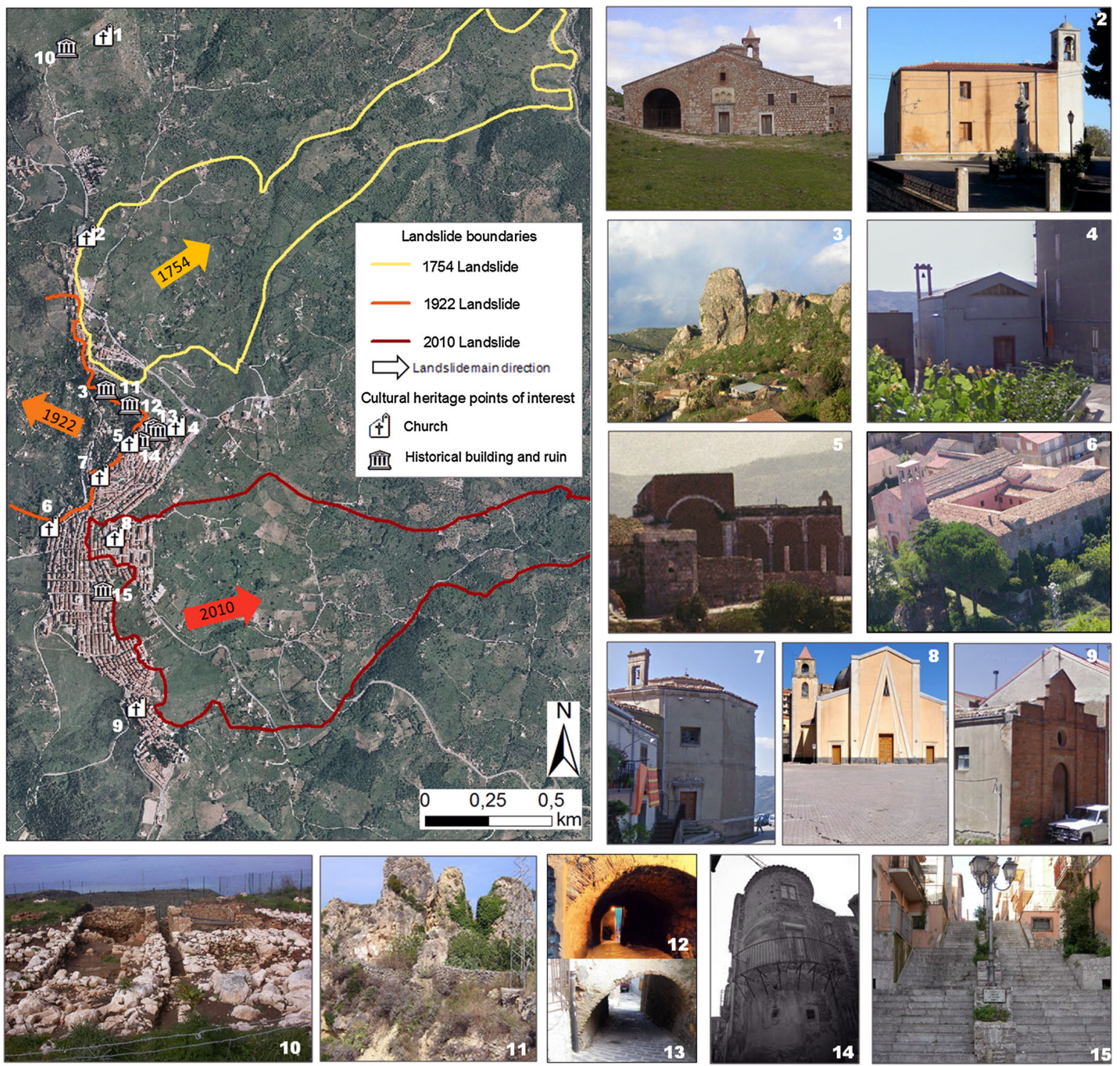

Figure 2

Boundaries and main directions of the three most important and recorded landslides in San Fratello, occurring in 1754, 1922, 2010. Location and photos of the main cultural sites of interest: 1 sanctuary of the three Saints Alfio, Filadelfio and Cirino on the Old Mountain; 2 Maria St. delle Grazie Church; 3 rocky massif Roccaforte; 4 St. Antonio Abate Church; 5 St. Nicolò Old Cathedral; 6 complex of St. Maria Assunta, former convent of S.S. Maria di Gesù and library; 7 St. Crocifisso Church; 8 St. Nicolò New Cathedral (now demolished); 9 St. Benedetto Il Moro Church; 10 Apollonia Archeological site; 11 ruins of St. Filadelfio Castle; 12 St. Nicolò Arcway 13 Stesicorea Arcway; 14 Historical Mammana palace; 15 Historical Stairway of Vittorio Veneto knights

back to 1754 and almost completely destroyed the village. The most recent phenomena are recorded in 1922 and 2010 (Fig. 2). On 8 January 1922, a landslide occurred in the northwestern sector of San Fratello, causing hundreds of deaths; about ten thousand people were evacuated and another village (called Acquedolci) was built along the coast, as ordered by a Royal Decree (FARANDA 2010). However, San Fratello was re-populated again across time and, more recently, on 14 February 2010, another wide landslide, triggered by intense rainfall and extended up about $1 \mathrm{~km}^{2}$, developed on the opposite southern-eastern slope, causing huge damages to the roads and structures (Fig. 2). This landslide affected 
the eastern urban districts (i.e., the Stazzone and Riana districts) and the first boundary of damaged area was released on 22February 2010 (Fig. 2). About 2,000 inhabitants were initially evacuated, approximately 300 houses were slightly damaged and 50 needed to be demolished (D.R.P.C. 2010).

This latest landslide affected the whole E-facing slope, consisting of roto-translational slide and flow, and involving the surface debris cover, which is about $10 \mathrm{~m}$ thick and mainly made of wet and fissured clayey lithotypes. As a result, the phenomenon has been caused by predisposing variables that deal with soil and rock geo-mechanical properties, and with the geostructural and hydrogeological setting of the area. The triggering factors may have been the intense rainfall that has increased the static water table within the shallow aquifer, determining soil saturation processes in the clays and causing mass movements.

Ground movements kept on being active up to nowadays, and, thus, the instability scenario is still very critical in San Fratello area.

\section{Cultural Heritage}

San Fratello is an old village, characterized by several sites of cultural-artistic interest that have been affected by the long-lasting catastrophic natural phenomena (Fig. 2). The remains of the very first inhabited territory of San Fratello, dating back to the III century B.C., are located uphill on the Old Mountain (718 $\mathrm{m}$ a.s.l.), northward of the present town (Fig. 2, point 1), where the ancient Norman Sanctuary of the three Saints, built up in the XII century, is also located (Fig. 2, point 1). Since the Norman age, San Fratello village expanded near the rocky massif called Roccaforte (Fig. 2, points 3 and 11) and developed until the Middle Age, when many churches and religious sites were built across time. Thus, on the one hand ,San Fratello was a rural village, mainly inhabited by farmers and artisans, but on the other hand, about a hundred households were among the richest and most powerful of Sicily region and undertook a struggle for possessions and interests even in building and embellishing the churches of the town: some examples are the St. Crocifisso Church characterized by an octagonal medieval shape plant
(Fig. 2, point 7), the St. Maria delle Grazie Church dating back to the XVIII century (Fig. 2, point 2), the St. Benedetto il Moro Church (Fig. 2, point 9) and the St. Antonio Abate Church (Fig. 2, point 4).

Many cultural sites of San Fratello have been destroyed by landslides and re-built again across time. The landslide that occurred on 8th January 1922 destroyed most of the town (about two-thirds of San Fratello village). The Maria St. Assunta motherchurch, built in the XIII century in the western portion of San Fratello, was completely destroyed by the phenomenon. The newly built Maria St. Assunta church, together with the former convent of Santissima Maria di Gesù and the library (Fig. 2, point 6), can be regarded today as the center of religion, culture and art of San Fratello.

The Old St. Nicolò Cathedral (Fig. 2, point 5), dating back to the XVI century, has been severely damaged by the 1922 landslide and nowadays the only remaining portions are the right sector and the lower part of the bell tower. In the 50s a new St. Nicolò Cathedral was built in the modern Stazzone district (Fig. 2, point 8). Unfortunately also this church has been affected by the 14 February 2010 landslide and has recently been demolished, in February 2013, due to the irreversible and non-repairable damages.

The majority of the historical old houses of San Fratello, the oldest ones dating back to the Norman settlement, have remained uninjured after the natural disasters up to nowadays (Fig. 2, points 12-15). Hence, the damage assessment and conservation strategies for the cultural heritage are strongly recommended and can be addressed to the most important sites of interest of the village.

\section{Methodology}

The approach of this work consists in a multitemporal and spatial investigation of landslide effects by means of PSI technique and field survey (Fig. 3). Firstly, we analyzed the available PSI data that highlighted ground motions in historical, recent and current time intervals. A down slope projection of Line-of-Sight (LOS) velocities was performed, following the procedure of COLESANTI and WASOWSKI 


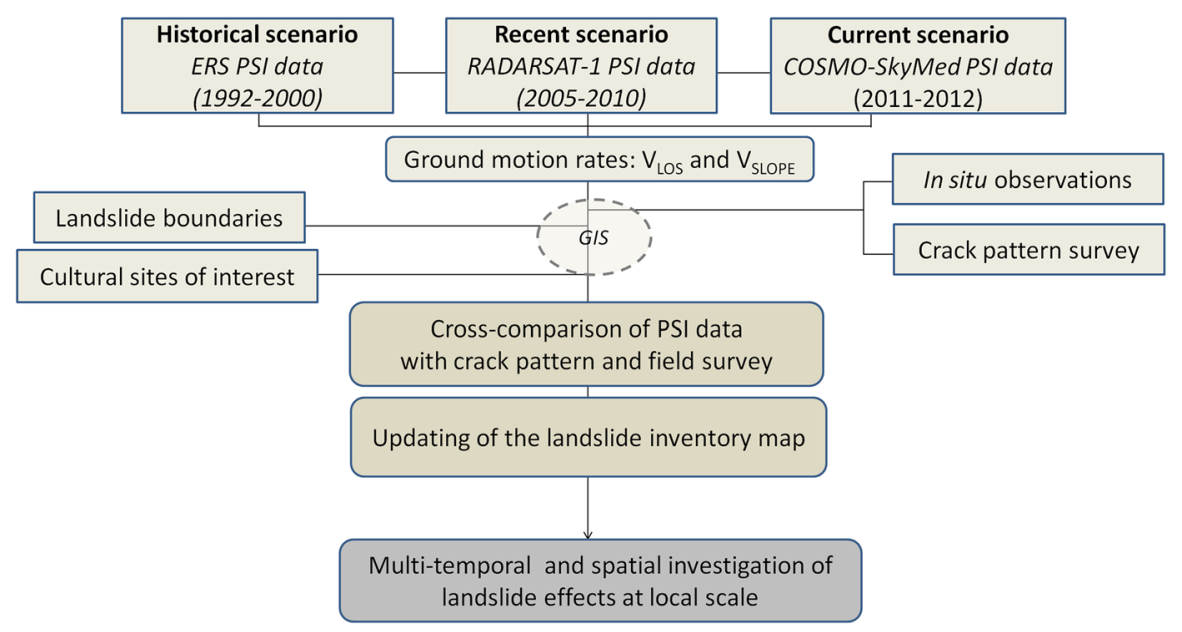

Figure 3

Methodology flow chart

(2006), in order to homogenize all the PSs in the same direction of the maximum local slope, and to obtain vectors of displacement that account more specifically for topographic features of landslides phenomena.

Then, radar movement rates were cross-validated and compared with local failures and with the in-situ observations on historical buildings carried out in the spring of 2010 and in the winter of 2012-2013. The radar mapping and subsequent zoning of the unstable urban sectors of San Fratello were performed by focusing on individual targets, i.e., buildings within the built-up area. In particular, PSI data, local cadastre, the distribution of churches and sites of cultural interest, and pre-existing landslide boundaries were compared and over-layered in a Geographical Information System environment (Fig. 3).

Radar-interpretation and photo-interpretation procedures (e.g., FARINA et al. 2006; BiANCHini et al. 2012; Cigna et al. 2013; Righini et al. 2012) combined with a field survey allowed the mapping and characterization of landslides. In particular, on the one hand, the recognition of features related to topographic surface movements and the typology classification were mainly based on visual interpretation of orthophotos; on the other hand, the evaluation of the velocity and state of activity of phenomena took advantage from multi-interferometry-based information. For newly detecting and enlarging phenomena, the two most recent available datasets (i.e., RADARSAT-1 and COSMOSkyMed data) were employed when improving the landslide inventory map of the study area.

Only "very slow" and "extremely slow" phenomena (velocity $<16 \mathrm{~mm} / \mathrm{year}$ and $16 \mathrm{~mm} / \mathrm{year}$ $\leq$ velocity $<1.6 \mathrm{~m} /$ year, respectively, according to Cruden and Varnes 1996) can be detected by PSI data due to the satellite technical acquisition parameters (i.e., signal wavelength and revisiting time; CANUTI et al. 2004). Moreover, N-S oriented ground movements are not or only partially illuminated by InSAR sensors, due to the intrinsical acquisition parameters of the satellites that move along $\mathrm{N}-\mathrm{S}$ orbits with a right-side looking system.

Overall, the outcomes of the work leads to an accurate mapping and monitoring of ground motions and impacts at a local scale, permitting proposing new boundaries of the landslide-affected areas in San Fratello village, and to update the landslide inventory map of the site (Fig. 3).

\section{InSAR Processing and Data}

Available radar data used in this work consist of SAR images acquired in historical (1992-2001), recent (2005-2010) and current (2011-2012) time intervals. In particular, in C-band $(5.6 \mathrm{~cm}$ wavelength), 104 SAR images were acquired by ERS 1/2 
Table 1

Main acquisition characteristics of the used SAR datasets and PSI velocity values before and after downslope projection of LOS values

\begin{tabular}{|c|c|c|c|}
\hline Satellite & ERS $1 / 2$ & RADARSAT-1 & COSMO-SKYMED \\
\hline Microwave band & $\mathrm{C}$ & $\mathrm{C}$ & $\mathrm{X}$ \\
\hline Acquisition mode & Ascending and descending & Ascending and descending & Descending \\
\hline Incidence angle $\left({ }^{\circ}\right)$ & 23 & 34 & 26 \\
\hline \multirow[t]{2}{*}{ Track angle $\left({ }^{\circ}\right)$} & 348 & 349 & 185 \\
\hline & 192 & 191 & \\
\hline Repeat cycle (days) & 35 & 24 & 4 \\
\hline Cell resolution in azimuth $(\mathrm{m})$ and range $(\mathrm{m})$ & $4 \times 20$ & $4 \times 10$ & $3 \times 3$ \\
\hline Critical baseline (m) & 1,286 & 1,825 & 5,728 \\
\hline \multirow[t]{2}{*}{ Number of SAR images } & 34 Ascending & 46 Ascending & 32 \\
\hline & 70 Descending & 47 Descending & \\
\hline Temporal span & 1992-2001 & $2005-2010$ & 2011-2012 \\
\hline \multirow[t]{4}{*}{ Acquisition dates interval } & Ascending & Ascending & 16/05/2011-02/05/2012 \\
\hline & $11 / 09 / 1992-05 / 06 / 2001$ & $30 / 12 / 2005-26 / 01 / 2010$ & \\
\hline & Descending & Descending & \\
\hline & 01/05/1992-08/01/200 & $31 / 01 / 2005-03 / 02 / 2010$ & \\
\hline Processing technique & SqueeSAR ${ }^{\mathrm{TM}}$ & SqueeSAR ${ }^{\mathrm{TM}}$ & SqueeSAR ${ }^{\mathrm{TM}}$ \\
\hline PS density (PS/ $\left.\mathrm{km}^{2}\right)$ & 16 & 112 & 400 \\
\hline \multirow[t]{2}{*}{$\mathrm{V}_{\text {LOS }}$ PSI data velocity range $(\mathrm{mm} / \mathrm{yr})$} & Ascending $(-9.5,+7.2)$ & Ascending $(-46.8,+19.8)$ & $(-56.4,+31.8)$ \\
\hline & Descending $(-26.8,+8.6)$ & Descending $(-26.3,+20.5)$ & \\
\hline \multirow[t]{2}{*}{ Correction factor $(C)$} & Ascending $(-0.33,+0.96)$ & Ascending $(-0.54,+0.99)$ & $(-0.45,+1.00)$ \\
\hline & Descending $(-0.41,+0.96)$ & Descending $(-0.52,+1.00)$ & \\
\hline \multirow{2}{*}{$\begin{array}{c}\text { Maximum } V_{\mathrm{SLOPE}} \\
\text { values }\left(V_{\mathrm{LOS}} / C\right)\end{array}$} & Ascending $(-33.4,+6.8)$ & Ascending $(-142.1,+146.6)$ & $(-119.8,+111.3)$ \\
\hline & Descending $(-84.5,+50.0)$ & Descending $(-71.5,+21.0)$ & \\
\hline \multirow[t]{2}{*}{$\mathrm{V}_{\text {SLOPE }}$ PSI data velocity range $(\mathrm{mm} / \mathrm{yr})$} & Ascending $(-33.4,+0.0)$ & Ascending $(-142.1,+0.0)$ & $(-119.8,+0.0)$ \\
\hline & Descending $(-84.5,+0.0)$ & Descending $(-71.5,+0.0)$ & \\
\hline
\end{tabular}

satellites in the period 1992-2001 in ascending (34 scenes) and descending orbit (70 scenes), and 93 SAR images were acquired by RADARSAT- 1 satellite, in ascending (46 images) and descending (47 images) modes, in the spanning time 2005-2010. Moreover, 32 SAR scenes were collected by COSMO-SkyMed satellite in X-band (3.1 cm wavelength) in descending geometry, in a 1 year-long period from May 16th, 2011 to May 2, 2012 (Table 1).

All the SAR images were processed through the SqueeSAR ${ }^{\mathrm{TM}}$ algorithm (FERRETTI et al. 2011) to obtain PSI data. The SqueeSAR ${ }^{\mathrm{TM}}$ is a new multitemporal interferometric processing technique, being an advance on the PSInSAR ${ }^{\mathrm{TM}}$ algorithm (FERRETTI et al. 2011), which permits measurement of ground displacements by means of traditional Permanent Scatterers (PS) like buildings, rock and debris, as well as from Distributed Scatterers (DS). DS are homogeneous areas spread over a group of pixels in a SAR image such as rangeland, pasture, shrubs and bare soil. These targets do not produce the same high signal-to-noise ratios of PS, but are, nonetheless, distinguishable from the background noise and their reflected radar signals are less strong, but statistically consistent. The SqueeSAR ${ }^{\mathrm{TM}}$ algorithm was developed to process the signals reflected from these lowreflectivity homogeneous areas, but it also incorporates PSInSAR ${ }^{\mathrm{TM}}$; hence, no information is lost and movement measurement accuracy is improved (FERRETTI et al. 2011). As a result, the SqueeSAR ${ }^{\mathrm{TM}}$ algorithm extracts geophysical parameters not only from point-wise deterministic objects (i.e., PS), but also from DS. PS and DS are jointly processed taking into account their different statistical behavior. The coherence matrix associated with each DS is properly "squeezed" to provide a vector of optimum (wrapped) phase values (Ferretti et al. 2011). The SqueeSAR ${ }^{\mathrm{TM}}$ technique allows an increase of density of the point targets that register ground motion, especially in non-urban areas, as sparse vegetation landscapes (MeISINA et al. 2013; RASPINI et al. 2013; Bellotti et al. 2014). 

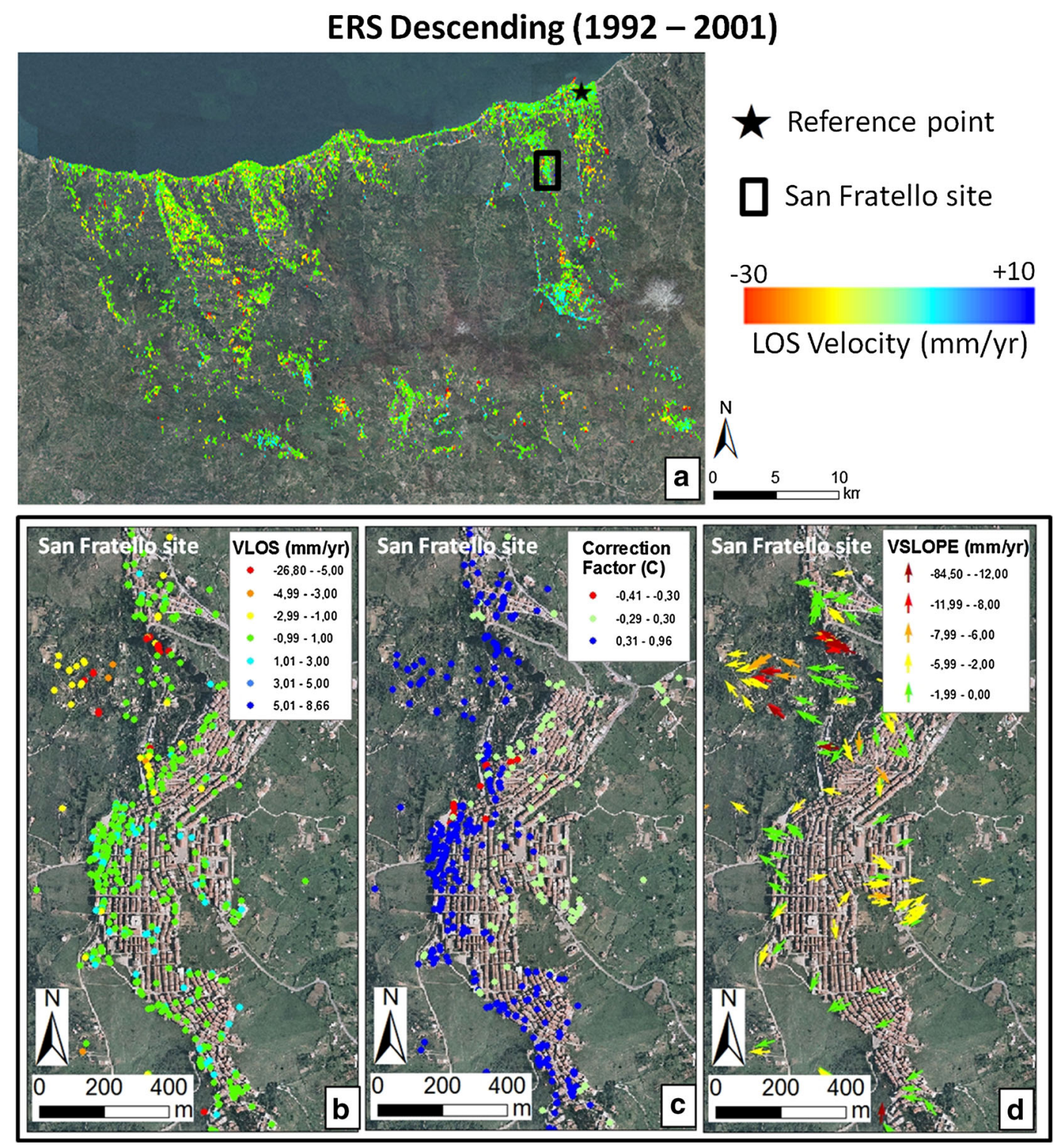

Figure 4

ERS PSI dataset in descending geometry within the study area: a PS LOS data distribution and reference point location; $\mathbf{b} V_{\mathrm{LOS}}$ values on the San Fratello village; c correction factor $(C)$ distribution values; $\mathbf{d} V_{\mathrm{SLOPE}}$ values on the San Fratello village

Persistent Scatterer Interferometry datasets for each satellite used on the San Fratello village in descending geometry are shown in Figs. 4, 5 and 6

Since satellite systems measure velocities just along their LOS, only the component of motion that is parallel to the LOS direction is measured. A projection of the LOS displacement measures along the most probable direction of movement can be performed. Thus, assuming a simple translational movement parallel to the slope, in this work LOS velocity of each available PS point ( $\left.V_{\mathrm{LOS}}\right)$ was projected along the direction of the maximum slope $\left(V_{\text {SLOPE }}\right)$, in order to account more specifically for topographic and geomorphological slope conditions within a local-scale landslides analysis. Moreover, this conversion permits comparing landslide velocities with different slope orientations, resolving the satellite acquisition orbit differences and allowing a more feasible interpretation. 

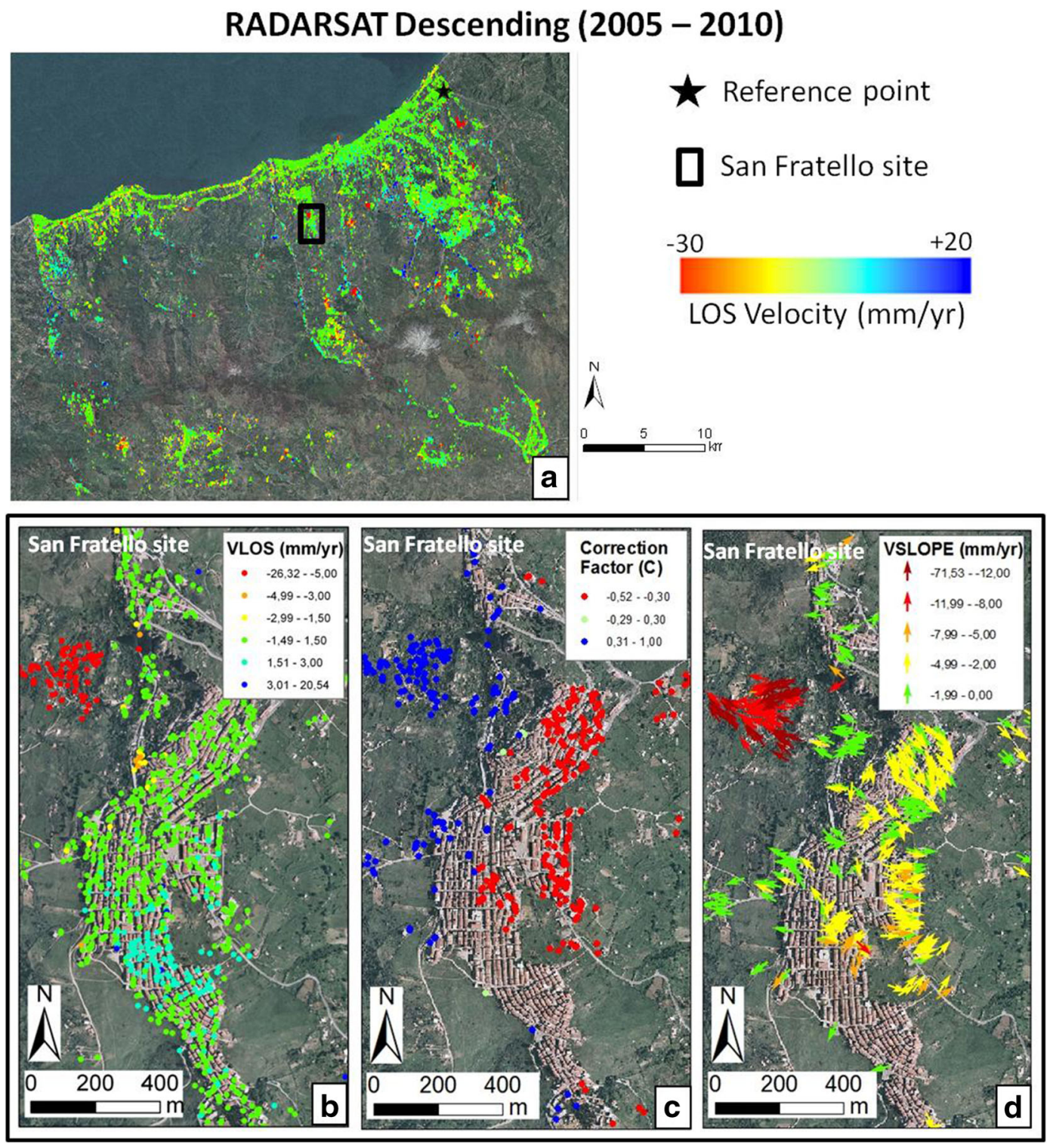

Figure 5

RADARSAT-1 PSI dataset in descending geometry within the study area: a PS LOS data distribution and reference point location; b $V_{\text {LOS }}$ values on the San Fratello village; c Correction factor $(C)$ distribution values; d $V_{\text {SLOPE }}$ values on the San Fratello village

Following the procedure initially proposed by Colesanti and Wasowski (2006), and then successfully applied in several scientific works (CigNa et al. 2013; Grief and VlCKo 2012; BiAnChini et al. 2013; Herrera et al. 2013), a correction factor (C) was applied to each LOS measurement, in order to determine the "real" $V_{\text {SLOPE }}$ velocity (intended as not the one measured in the LOS direction, but the one occurring in the landslide direction), taking into account satellite-dependant parameters, i.e., incidence angle and track angle, as well as topographic parameters, i.e., terrain slope and orientation, The track angle and the incidence angle are provided within the processed SAR images for each satellite (Table 1). The slope and aspect of the area of interest are derived from a DEM with $20 \mathrm{~m}$ cell resolution.

The $C$ correction factor represents the fraction of movement that can be registered by the SAR sensor, ranging from a negative value up to 1 . It depends on the angle between the steepest slope and the LOS 


\section{COSMO-SkyMed Descending (2011 - 2012)}
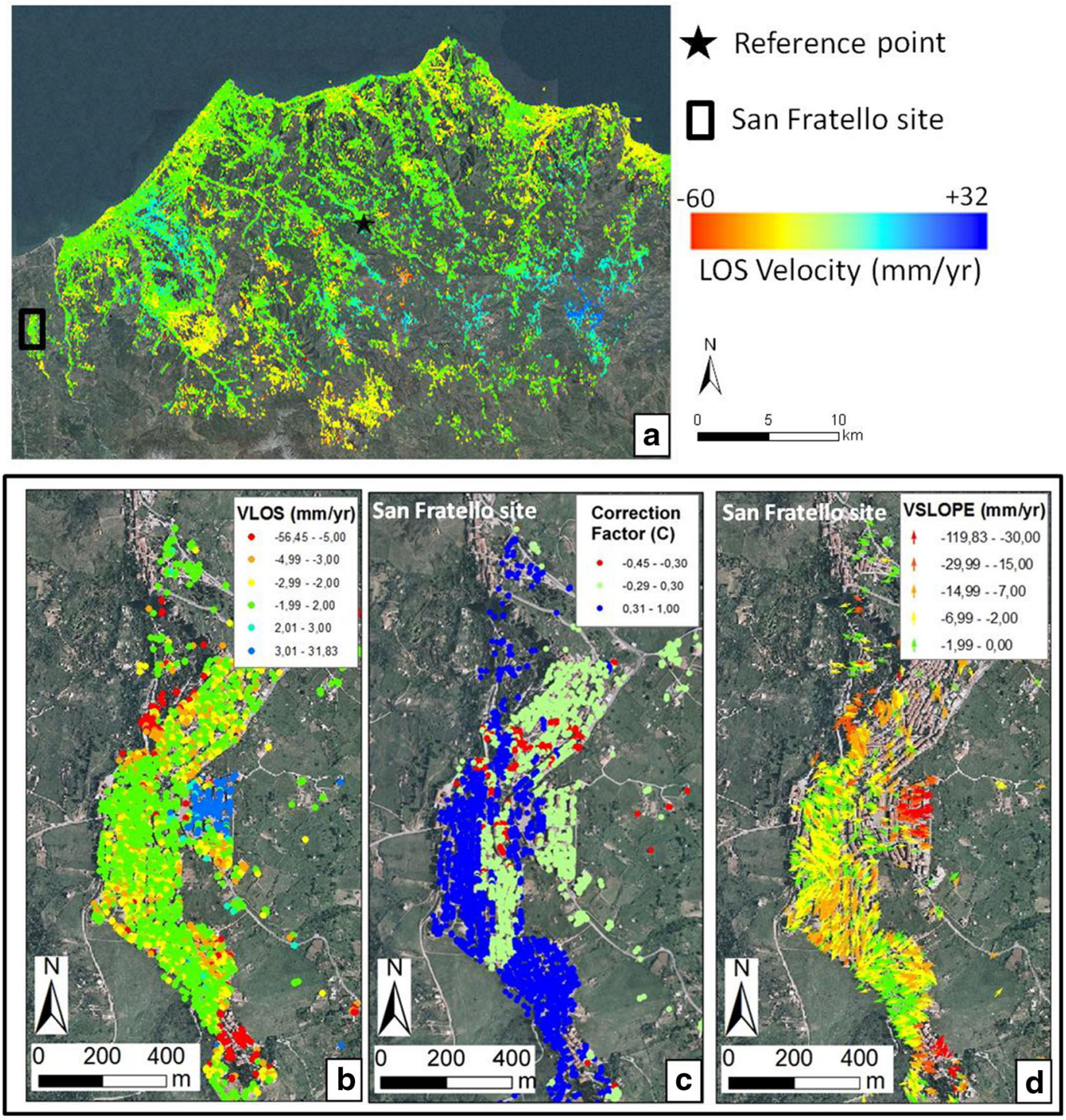

Figure 6

COSMO-SkyMed PSI dataset in descending geometry within the study area: a PS LOS data distribution and reference point location; $\mathbf{b} V_{\text {LOS }}$ values on the San Fratello village; c correction factor $(C)$ distribution values; d $V_{\text {SLOPE }}$ values on the San Fratello village

direction, being close to 0 when this angle is almost $90^{\circ}$. The factor $C$ shows negative values when the movement is registered with reverse direction. The $V_{\text {SLOPE }}$ values are obtained through the $V_{\mathrm{LOS}} / C$ ratio (BiAnChini et al. 2013) (Figs. 4, 5, 6). When the $C$ value is close to 0 , then the $V_{\mathrm{SLOPE}}$ rate tends to infinity. In order to reduce any exaggeration of the downslope projection when $C$ tends towards 0 , we set $C=-0.3$ when $-0.3<C<0$ and $C=0.3$ when $0<C<0.3$, according to previously tested procedures (BIANCHINI et al. 2013; HERRERA et al. 2013). The maximum $V_{\text {SLOPE }}$ values obtained after the downslope projection calculations, as well as the PS velocity distribution features are included in Table 1.

It is worthwhile to highlight that PS rates on flat areas (slope gradient lower than $5^{\circ}$ ) were not projected downslope and that positive $V_{\mathrm{SLOPE}}$ values, which would represent uphill movement, were discarded, following the approach of BIANCHINI et al. 
(2013) and Herrera et al. (2013). This is because landslide occurrence on almost flat areas is very rare and positive $V_{\text {SLOPE }}$ values indicate that a landslide is going up the slope. Although positive movements may be present at the toe of landslides where vertical displacements can occur, the horizontal vector of the movement should remain oriented downhill (HERRERA et al. 2013).

$V_{\text {LOS }}$ and $V_{\text {SLOPE }}$ measurements of each satellite employed within the analysis on San Fratello village, as well as the $C$ factor values, are shown in Figs. 4, 5 and 6, As the coefficient $C$ represents the percentage of real motion measured by the satellite, the projectability map showing $C$ distribution reveals the amount of velocity along the local slope seen for each PS and can be considered as a quantitative evaluation of the projection procedure of $V_{\mathrm{LOS}}$ along the local slope.

The pre-existing available inventory map of the study area is the Piano Assetto Idrogeologico (PAI, Hydrogeological Setting Plan), which is dated up to 2012 and includes landslide phenomena classified according to the type and the state of activity. The most representative typologies are slow-moving complex, translational slides, and earth slips. Landslides are classified as active, dormant, inactive (including relict and abandoned phenomena) and stabilized, according to a simplified version of CRUDEN and VARNES (1996) classification.

In situ observations and crack pattern survey were performed in two different time periods: just after the 2010 landslide, and during the period November 2012-January 2013.

Field surveys focused on both ground surface cracks and building cracks. Fractures on buildings were qualitatively classified with respect to orientation (vertical, oriented or horizontal) and typology, according to AleXANDER (1989) (Fig. 7a, b). Although building cracks differently develop according to building material and foundation typology, from the features and distribution of the crack system observed on the facades, the main cause and movement direction can be supposed (HARP 1998). Some examples are shown in Fig. 7c. Many extension cracks with a unique dip direction on a facade reveal a failure due to a differential foundation settlement induced by a translational movement
(Fig. 7c1). Cracks showing up as an arc on a facade can be induced by a sinking motion of the foundation (Fig. 7c2). Vertical extensional cracks are usually caused by a translational mass movement and show up orthogonally to the main tensile stress direction (Fig. 7c3) (Di Romolo 2008).

\section{Cross-Validation Between PSI Data and the Field Survey}

Radar-interpretation combined with photo-interpretation analysis (FARINA et al. 2006) permitted one to successfully update the pre-existing inventory map of the whole area around San Fratello village, extended up about $25 \mathrm{~km}^{2}$ (ADB 2012). In particular, this procedure allowed detecting some new potentially hazardous areas and enlarging the boundaries of most of the already mapped phenomena (BIANCHINI et al. 2014) (Fig. 8).

At a more detailed and local scale, PSI analysis compared with the in situ survey was exploited over the urban fabric of San Fratello village. Historical, recent and current PS $V_{\mathrm{LOS}}$ and $V_{\mathrm{SLOPE}}$ ground motion rates were analyzed for instability detection over the most significant areas of San Fratello, primarily considering the distribution of the sites of cultural interest of the village and the boundaries of the two most recent catastrophic landslides occurring in 1922 and 2010.

The soil crack pattern mapping within San Fratello built-up area was performed just after the 2010 landslide. Moreover, further and more recent sitespecific field checks and building cracks surveys were carried out in November 2012 and January 2013, in order to validate PSI-based impact assessment performed at a desk, prior to in situ investigations.

At the northern entrance of San Fratello, where the Church of St. Maria delle Grazie is located on a raised position close to the road running along the slope crest (Fig. 9), the spatial distribution of $V_{\mathrm{LOS}}$ and $V_{\text {SLOPE }}$ displacements in the historical time period (ERS descending data in 1992-2000) seems to show a quite relative stability over the buildings and infrastructure (i.e., yearly motion rate not exceeding $\pm 2.0 \mathrm{~mm} /$ year), with no PS identified over the east-facing slope. Nevertheless, PS RADARSAT-1 
data acquired in the recent period (2005-2010) reveal a significant ground instability of the area, with velocity rates up to $-15 \mathrm{~mm} / \mathrm{year}$ along the slope. Field checks also allowed the recognition of indicators of landslide movements and soil creep over the upper part of the slope, such as the loss of verticality of the lights poles and vineyards (Fig. 9). Furthermore, a severe crack pattern affects the concrete structures and retaining walls located along the scarp. The presence of extension fractures, with wide aperture up to $2 \mathrm{~cm}$ (Fig. 9), confirms the slowmoving slide displacement downslope, permitting one to locally update the pre-existing landslide inventory accordingly (Fig. 9).

High motion rates were detected in historical, recent and current time periods, in and close to the two main landslides occurring on opposite slopes in
Figure 8

Updating of the landslide inventory map within the whole study area around San Fratello village: a Pre-existing landslide inventory map from PAI (Piano di Assetto Idrogeologico-Hydrogeological Setting Plan) referred to 2012 (ADB 2012). Phenomena are classified according to typology and state of activity; b Improved landslide inventory map updated to 2012 by means of photointerpretation and radar-interpretation. Phenomena are classified according to typology and comparison with a pre-existing inventory map

1922 and 2010, affecting several urban sectors of San Fratello.

In particular, in the north-eastern portion of the village, both historical and recent PS data allow detecting the persistence of a suspicious W-directed displacement pattern over an enclosed sector within the area of the 1922 landslide, north-westward of the old districts of the village (Fig. 10). The yearly
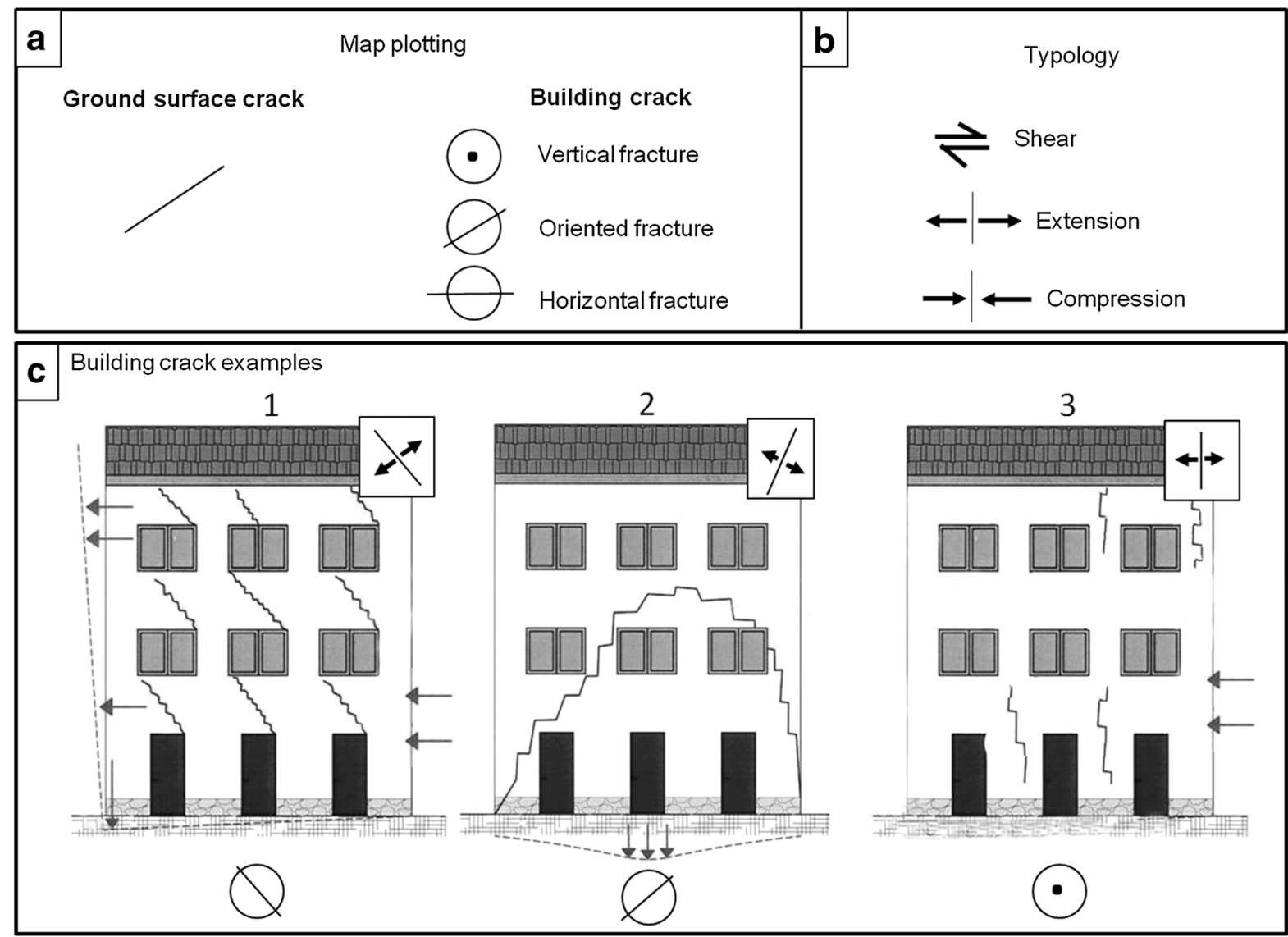

Figure 7

Symbology for ground surface and buildings cracks: a symbology for plotting cracks on the map; b typology of cracks (from ALEXANDER 1989); c building crack examples (modified from: http://www.controllofessure-mg.it/): 1 oriented extensional cracks showing a unique orientation and dip direction; 2 extensional cracks distributed as "an arc" on the building façade; 3 vertical tension cracks 

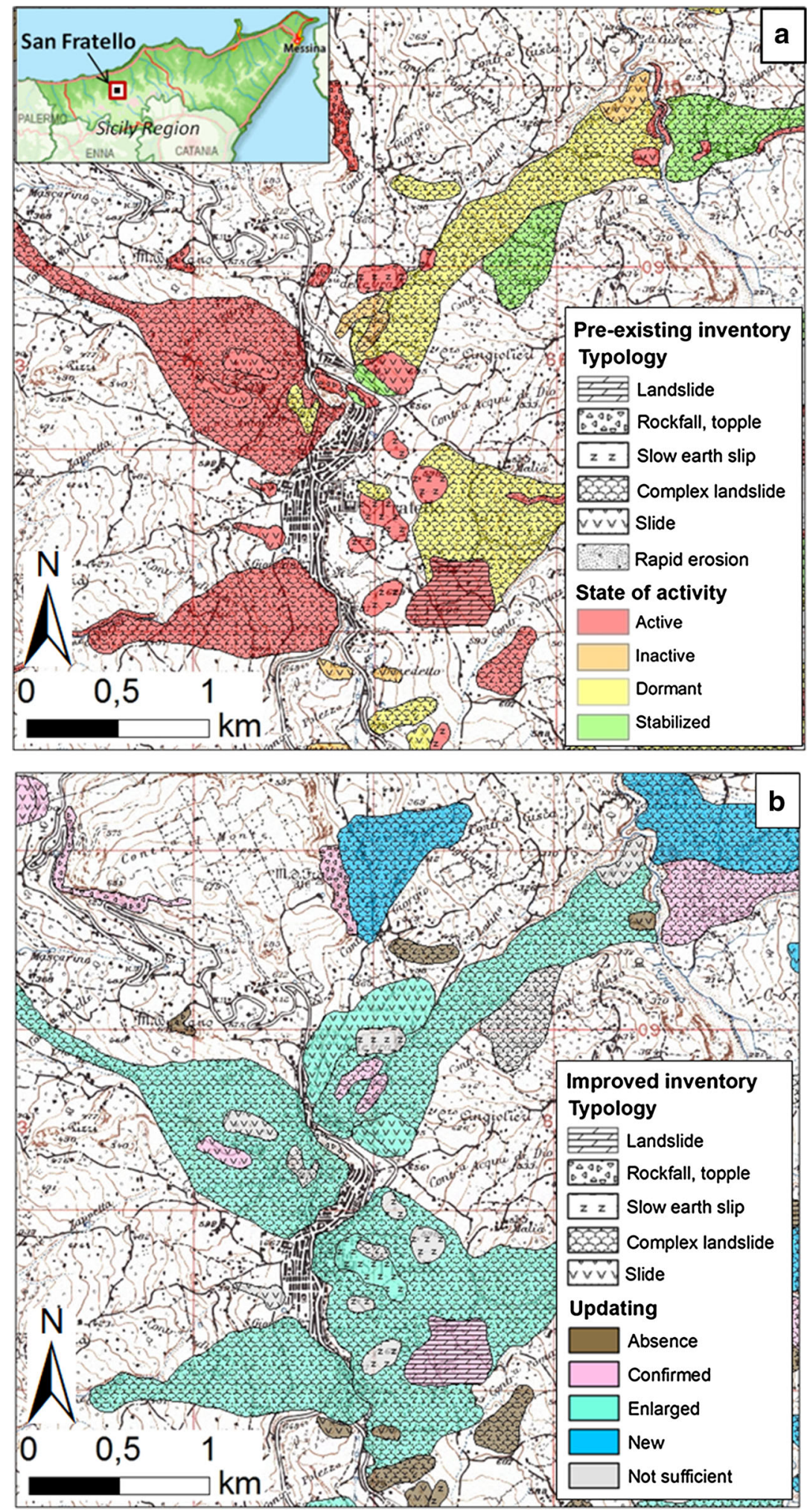

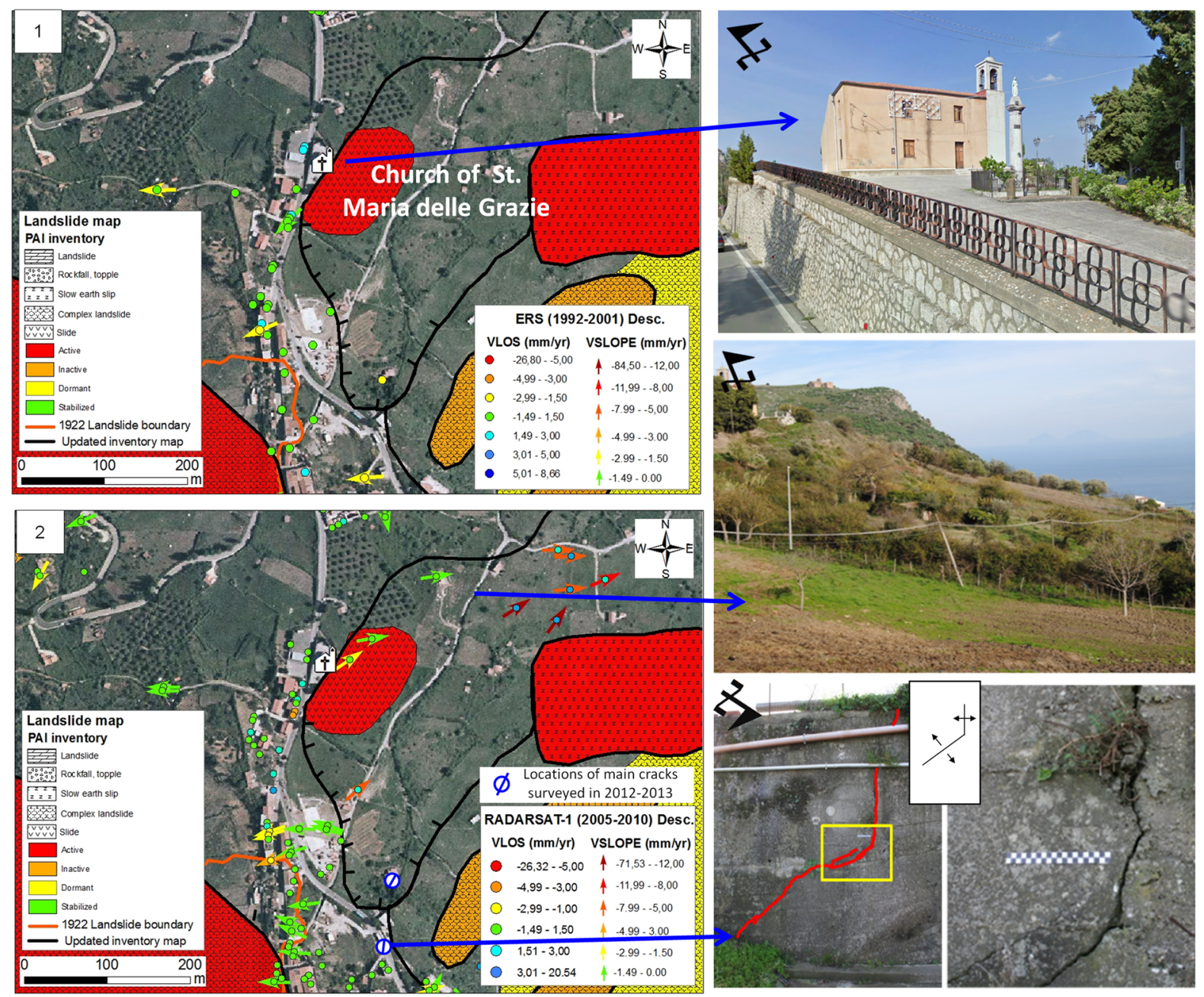

Figure 9

Northern portion of San Fratello village: 1 PSI ERS ( $V_{\text {LOS }}$ and $\left.V_{\text {SLOPE }}\right)$ displacement map in the historical time interval, $1992-20012$ PSI RADARSAT-1 ( $V_{\mathrm{LOS}}$ and $\left.V_{\mathrm{SLOPE}}\right)$ displacement map in the recent time interval, 2005-2010. Photos are explained within the text

motion rates reach values of $-6 \mathrm{~mm} /$ year measured along the LOS $\left(V_{\mathrm{LOS}}\right)$ and $-11 \mathrm{~mm} /$ year along the local slope $\left(V_{\mathrm{SLOPE}}\right)$ in the historical period (ERS data), and values ranging from -5 to $-14 \mathrm{~mm} /$ year and from -8 to $-19 \mathrm{~mm} / \mathrm{year}$, respectively, in the LOS and local slope directions, during the recent acquisition time (RADARSAT-1 data). These rates indicate that the area has been continuously unstable in the last 20 years, and allow confirming the boundary and state of activity of this landslideaffected sector of the slope. Persistent and comparable high ground motion rates from 1992 up to 2012 are also observable along the mapped 1922 landslide boundary, and needed to be taken into account, due to the near presence of some cultural sites of interest (the Roccaforte and the St. Filadelfio Castle ruins) (Fig. 10).

Close to the eastern boundary of the 1922 landslide, unexpected high displacement rates were detected (Fig. 11), especially by COSMO-SkyMed data, around the Old Cathedral of St. Nicolò, which was severely damaged by the 1922 landslide. Ground surface cracks and building fractures near the Old Cathedral of St. Nicolò were surveyed in November 2013. Radar-detected movements retrieved by COSMO-SkyMed show good correlation with the distribution and the opening of the cracks along the pavement, which are located orthogonally to the 

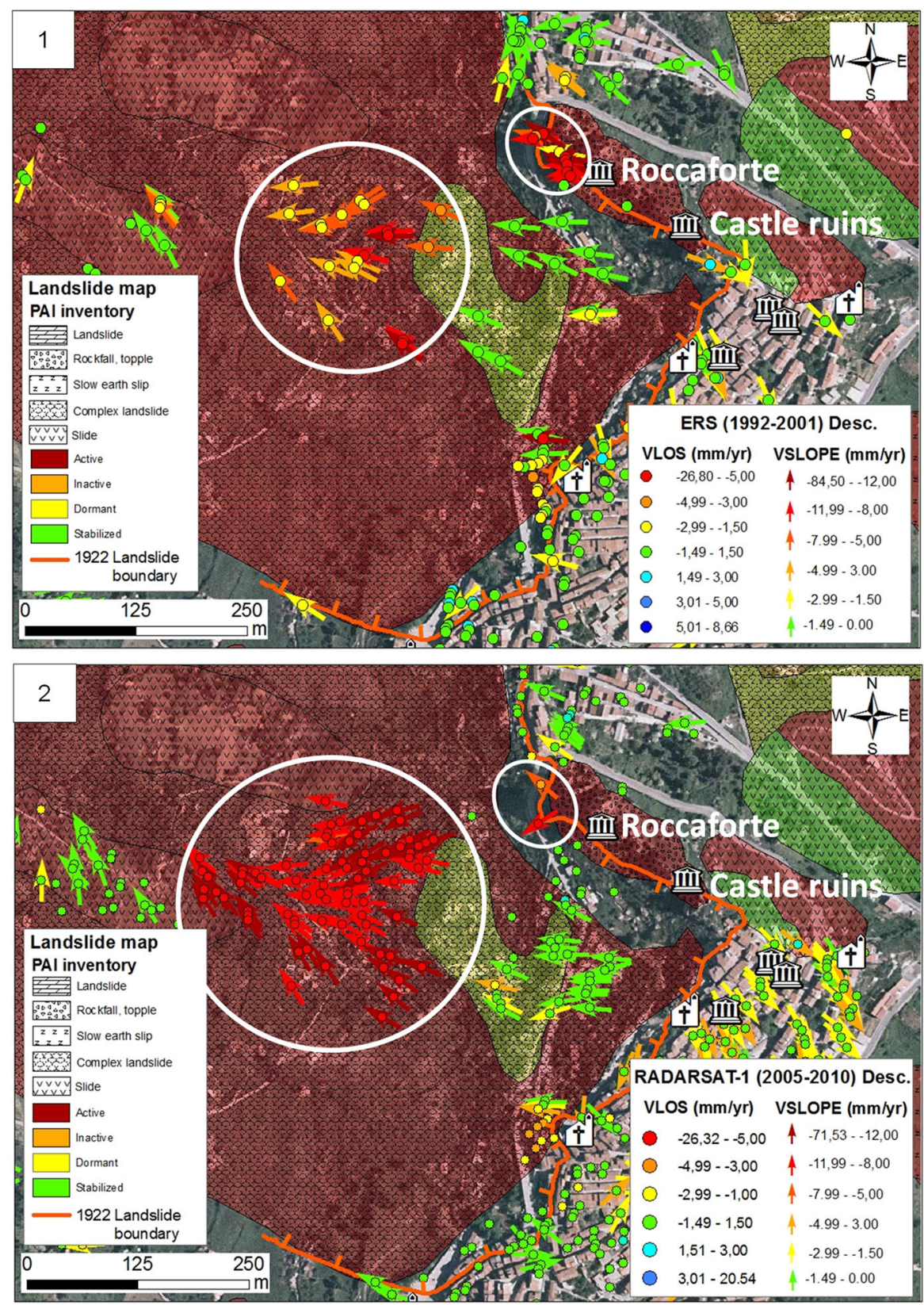

Figure 10

Area within the 1922 landslide on the W-facing slope in San Fratello village: 1 PSI ERS displacement map ( $V_{\text {LOS }}$ and $\left.V_{\text {SLOPE }}\right)$ in the historical time interval, 1992-2001; 2 PSI RADARSAT-1 ( $V_{\text {LOS }}$ and $\left.V_{\text {SLOPE }}\right)$ displacement map in the recent time interval, 2005-2010

ground motion direction, and along wall surfaces of the old districts. The vertical extension cracks observed on the walls reveal the subhorizontal vector of displacement. Overall, the instability affects the Old Cathedral of St. Nicolò and most of the surrounding civil buildings along the scarp, as well as the apparently stable Church of St. Crocifisso, with
$V_{\text {SLOPE }}$ displacement up to $-30 \mathrm{~mm} /$ year estimated in the most recent time interval, 2011-2012.

It is worth noting that for the Church of St. Crocifisso, the field checks completed the PS-based mapping of ground deformation. Although the radar processing did not provide a sufficiently dense set of PS over the monument neither in X-band, the in situ 


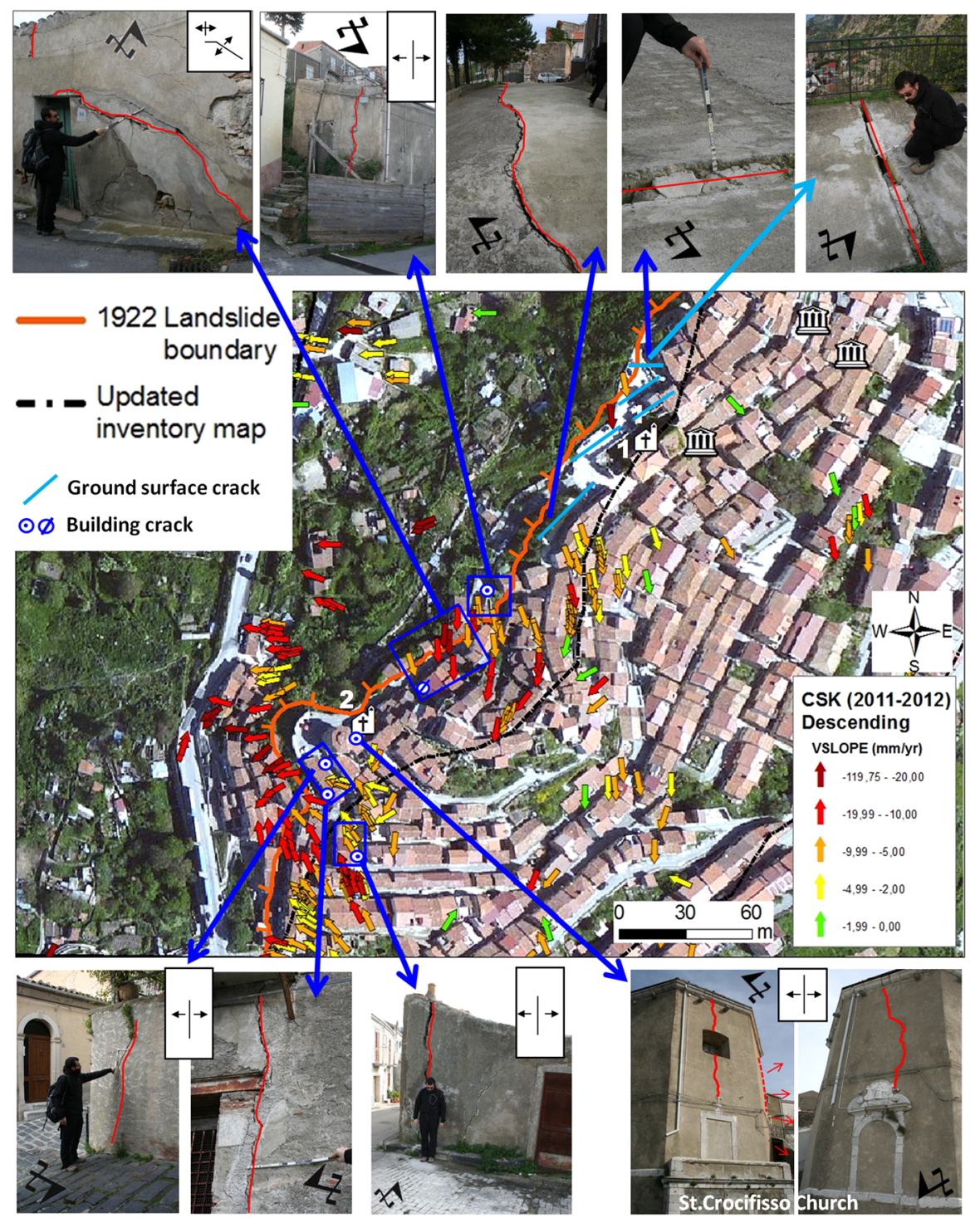

Figure 11

Displacement map of the area in and close to the crown of the 1922 landslide, representing the oldest reaming part of San Fratello village: $V_{\text {SLOPE }}$ COSMO-SkyMed PSI data acquired in 2011-2012 overlapped on a recent (2011) orthophoto. Above and below the map: photos showing some of the pavement and building cracks surveyed in November 2012-January 2013

inspections permitted one to discover and survey not only surface cracks, but also a sort of bulging of the external walls (Fig. 11), as a further indicator of the structural instability currently affecting the church, due to the general instability of the terrace on which it is built.

As a result, radar data validated with in situ data led us to assign a high level of criticality to the entire sector of the old districts along the scarp, and to update the boundary of the damaged area of the 1922 phenomenon, including further buildings and monuments within the crown of the ancient landslide. The proposed newly mapped boundary is shown in Fig. 11. Moreover, this area will need careful monitoring, since it is the oldest remaining part of San Fratello village.

Regarding the opposite slope and the area in and close to the 2010 landslide, PS data and field validation survey allowed the landslide boundary to be updated, thereby including further urban districts 

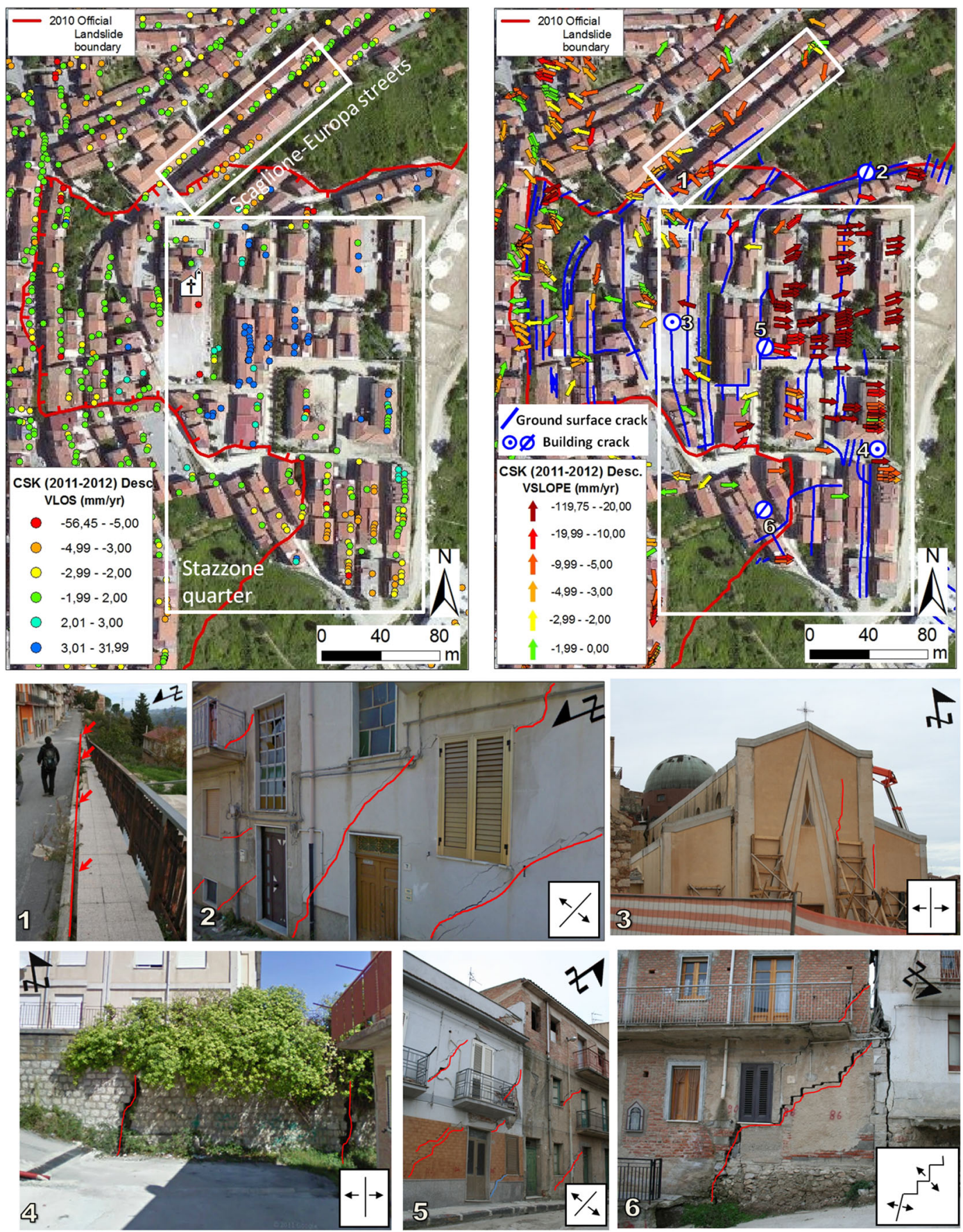

Figure 12

Displacement map of the area in and close to 2010 landslide, focusing on Scaglione-Europa streets area and Stazzone quarter: a $V_{\mathrm{LOS}}$ COSMO-SkyMed PSI data; b $V_{\text {SLOPE }}$ COSMO-SkyMed PSI data and cracks plotting: pavement cracks mapped in March 2010 and location of the main building cracks surveyed in November 2012-January 2013. Below the map: 1 pavement crack in Scaglione street (November 2012); 2 oriented extensional cracks on buildings in Fontana Nuova street (November 2012); 3 St. Nicolò New Cathedral (photo taken in November 2012), now demolished; 4 severely damaged wall in Generale Artale street (March 2010); 5 oriented extensional cracks on buildings in Pirandello street; 6 extensional cracks in Stazzoni street (November 2012) 

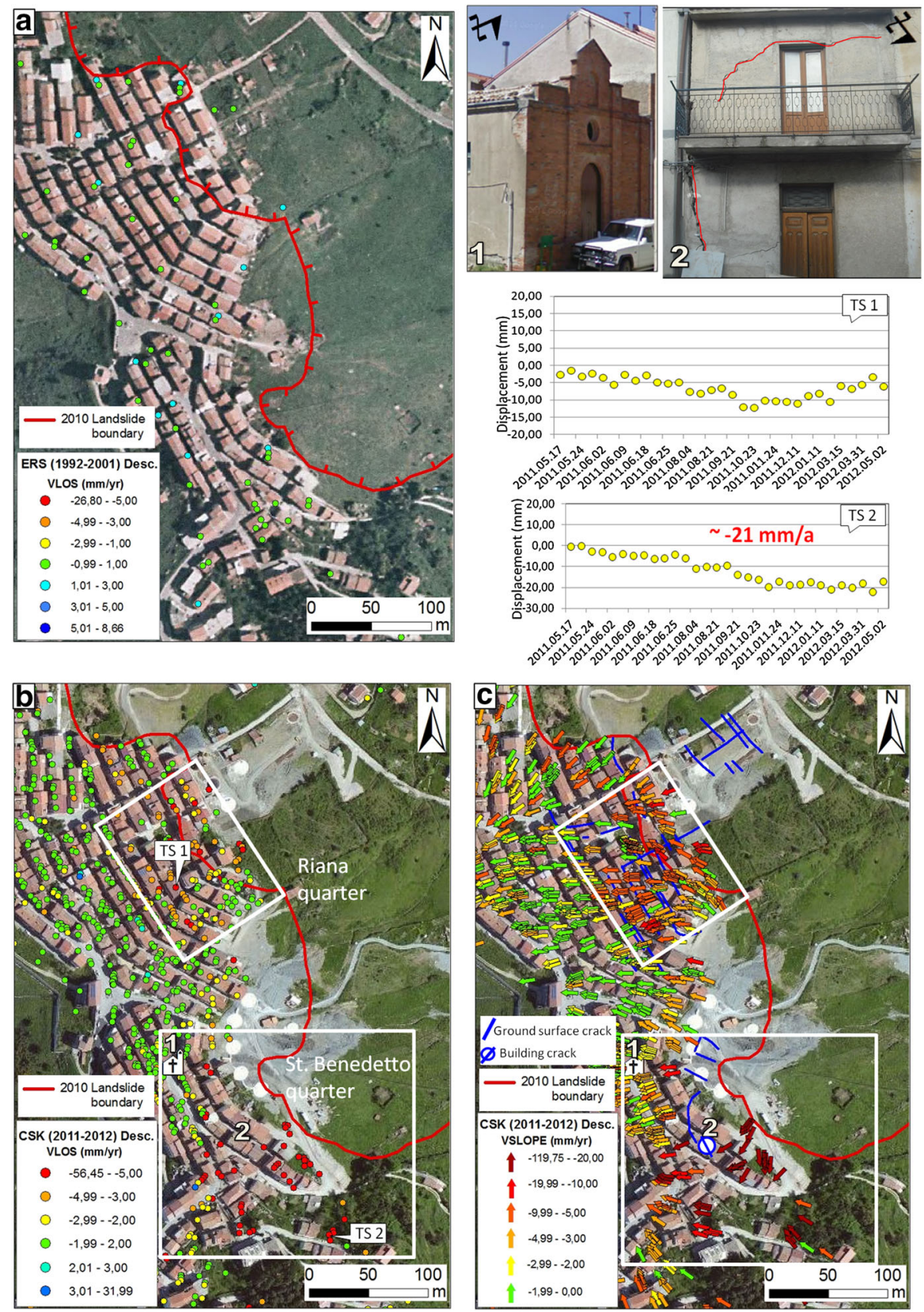

Figure 13

Displacement map of the area in and close to 2010 landslide, focusing on Riana and St. Benedetto districts: a $V_{\text {LOS }}$ ERS PSI data overlapped on a historical (2000) orthophoto (Volo Italia 2000) and time series of two selected PS targets; b $V_{\text {LOS }}$ COSMO-SkyMed PSI data overlapped on a recent (2011) orthophoto; $\mathbf{c} V_{\mathrm{LOS}}$ COSMO-SkyMed PSI data and cracks plotting, overlapped on a recent (2011) orthophoto. Photos: 1 St. Benedetto Il Moro Church; 2 Example of damages on a building in Roma street

previously not considered as being critical (Figs. 12, 13). COSMO-SkyMed (2011-2012) PS data in descending geometry show up on housetops and facades of buildings, enabling a highly detailed investigation and precisely detecting the buildings affected by ground deformation. In particular, four main areas located close to the official zoning of the 2010 landslide were definitely recognized as affected by ground motions instability in the last years of monitoring (Figs. 12, 13). A strong spatial correlation 
between the identified COSMO-SkyMed PS targets and the surveyed cracks and damages was found.

Northward of the 2010 landslide boundary, some PS show high motion rates, confirmed by the damages observed in situ along Scaglione and Europa streets. In particular, the presence of tension cracks along the pavement may indicate the occurrence of a surface ground deformation (D.R.P.C. 2010) (Fig. 12).

Another unstable area is the Stazzone district, located on the upper part of the 2010 landslide. The $\mathrm{N}-\mathrm{S}$-oriented cracks on the ground, mapped after the 2010 landslide, derive from tensile stresses within the translational landslide characterized by a main planar motion component (D.R.P.C. 2010). Severe crack patterns were found on the buildings of the whole quarter during the recent field survey, revealing that soil moved away from foundations. The New Cathedral of St. Nicolò was demolished in February 2013 due to non-repairable damages (Fig. 12).

PS data and field checks in the Riana district, located just out of the mapped landslide boundary, also reveal high motion rates up to $-12 \mathrm{~mm} / \mathrm{year}$ along the satellite LOS and up to $-15 \mathrm{~mm} /$ year along the steepest slope, during the acquisition period 2011-2012 (Fig. 13).

In the southern St. Benedetto district, ground deformations are the highest (up to $-21 \mathrm{~mm} /$ year in 2011-2012) and visible only through the current data measured by the satellite COSMO-SkyMed, while, in the previous periods, ERS and RADARSAT data do not reveal any movements (Fig. 13). Therefore, buildings in this part of the village started being affected by instability since 2011, as confirmed by the inhabitants and from the in situ survey carried out in November 2012.

In conclusion, thanks to the cross-comparison of local failures and displacement features of single edifices observed in situ with radar data, an updating of the pre-existing landslide inventory map of the whole study area was performed. In particular, within the San Fratello urban area, radar data validated by localized field checks allowed a new zoning of the western boundary of the 2010 landslide with respect to the official mapping released on 22 February 2010, enlarging it to include urban areas previously not considered as being unstable.
If the above result was reasonably expected in light of the state of activity and actual extent of the recent 2010 landslide, the satellite data evidenced critical conditions retrieved also for the historical districts of San Fratello along the scarp of the old 1922 landslide, proposing a new mapping also for the eastern boundary of this mapped phenomenon.

\section{Discussion}

The multi-temporal comparison of PS motion velocities of all the available datasets (i.e., ERS-1/2 1992-2001; RADARSAT-1 2005-2010; COSMOSkyMed 2011-2012) highlighted persistent ground deformation in San Fratello village, especially over the old districts around the crown of the 1922 landslide and along the western boundary of the 2010 landslide. In particular, COSMO-SkyMed data definitely proved the current critical condition of this sector of San Fratello, thereby increasing the alert level for an area otherwise classified as stable.

Ground motion within the area is assumed to be characterized by a steady-state nature, given the linear deformation model assumption made in the PSI processing approach (CROSETTO et al. 2010; HoOPER 2006). A linear regression model is fitted to the data within the processing technique, and, thus, PSI time series show a linear deformation trend in time (Fig. 13). As a result, the non-linear nature of the deformation cannot be analyzed by the PSInSAR ${ }^{\mathrm{TM}}$ and SqueeSAR ${ }^{\mathrm{TM}}$ (HoOPER 2006). However, in this case, the non-steady and episodic motion within the landslide is assumed to be actually small in magnitude, just determined by intense rainfall that cause acceleration and groundwater level change, because plastic deformations were recognized along the whole slope, being independent from the recently occurred catastrophic movements (D.R.P.C. 2010).

The affordability of X-band data rely on their potential for accurate deformation measurements that benefits from high spatial and temporal resolution. Overall, the use of X-band SAR sensors, i.e., COSMO-SkyMed, with high spatial resolution up to 1 meter (Roth et al. 2003; GeRnhARDT et al. 2010) and short revisiting time improves PSI capability for 
ground motions detection (BIANCHINI et al. 2013; Herrera et al. 2010; NotTi et al. 2010).

$\mathrm{X}$-band radar data turn out to be particularly suited for local detection of landslide processes at small scales, especially in urbanized areas, since the great density of PS point targets in X-band permits to better understand and accurately describe deformation phenomena, entering at the level of the site-specific ground motions investigation. In the San Fratello test site, COSMO-SkyMed data show a PS density 40 times higher than the one of the medium resolution satellite (i.e., ERS) (Table 1). These advantages improve the level of detail of the analysis and allow studying highly localized surface displacements and their dynamic evolution patterns. Although temporal decorrelation is more problematic at X-band compared to longer wavelengths like C-band, the highbandwidth data acquired by COSMO-SkyMed sensor permit more PSI targets to be identified, and so higher deformation gradients can be detected compared to C-band satellites (GE et al. 2010). This is due to the shorter monitoring period of only 12 months $(05 / 16 /$ 2011-02/05/2012) as well as to the shorter temporal sampling (up to 4 days), allowing the retrieving of more coherent pixels that show displacements. Some of the PS targets identified by X-band sensors would not be detected over a longer monitoring period or with a worst temporal resolution because the coherence would be lost.

The use of the new SqueeSAR ${ }^{\mathrm{TM}}$ algorithm (FERRETTI et al. 2011), exploiting both 'point-wise' PS and 'spatially distributed scatterers' (DS), increases the PS targets retrieval also in not-densely urbanized areas and produces improvements in the quality of the displacement time series (MEIsina et al. 2013; RASPINI et al. 2013). PSI technique is not a stand-alone technique, and it must be considered as a complementary support to the analyses of the areas affected by slope instability. Ground movement evidence obtained from radar data need always to be validated and compared as much as possible with other kinds of techniques and auxiliary information, in order to achieve a reliable investigation (FARINA et al. 2006; Righini et al. 2012). Thus, the combined use of radar data with traditional geomorphological tools like photo-interpretation, field surveys and in situ campaigns give useful effort for the mapping and monitoring of the impacts of landslide phenomena on buildings and manufactures of the investigated sites (Herrera et al. 2010; PARCharidis et al. 2010; Cigna et al. 2011; TAPETE et al. 2012; Frattini et al. 2013).

In this work, PSI radar-interpreted data were successfully cross-compared with a field survey, which includes observations on landslide-induced damages and crack pattern survey of urban structures. A good agreement between the satellite ground motion evidences and the ground truth was found in the San Fratello village.

In order to compare more specifically InSAR results with local failures and building damages, PSI data measured along the satellite LOS were projected downslope along the maximum steepest slope, following the approach presented and applied in previous works by the scientific community (COLESANTI and WASOWSKI 2006; CASCINI et al. 2009; CignA et al. 2012, 2013; Grief and VlCKo, 2012; BiANCHINI et al. 2013; HerRera et al. 2013).

The so-called $V_{\text {SLOPE }}$ values obtained through the projection of LOS displacement values ( $V_{\text {LOS }}$ ) allow a more intelligible interpretation of radar data with respect to the local morphology (Cigna et al. 2013; Bianchini et al. 2013). Several limitations need to be accounted for when projecting the velocity along the slope. The $V_{\text {LOS }}$ projection is only valid when the landslide movement is parallel to the slope, thus, this requirement typically holds for planar slides with slow flow but not for rotational landslides, which generally possess a vertical movement at the crown and horizontal movement at the toe. The landslide movements in San Fratello are mainly ascribed as translational slides associated with localized flows (D.R.P.C. 2010; ADB 2012), so they are compatible with the assumed limitations of the projection procedure. Moreover, $V_{\text {LOS }}$ values may vary due to vertical displacements, i.e., soil consolidation, which should not be projected, and, if the $V_{\text {LOS }}$ data are noisy, the projection will amplify any errors. In the San Fratello test site, in order to reduce these problems within the PSI analysis, the $V_{\text {SLOPE }}$ positive values were discarded as indicating uphill motion and only PS velocities over $5^{\circ}$ slope were projected since movement on flat areas (slope $<5^{\circ}$ ) would be related to other causes. As shown in Figs. 4, 5 and 6, for the same area of interest 
and the same satellite, the value of the correction factor $C$ can vary strongly with the irregularity of the slope. The real direction of motion is most likely more uniform. For this reason, when calculating the $C$ factor for performing the downslope projection, it is better to use a DEM with a lower resolution or resample a detailed DEM to smooth out these variations. In the San Fratello test site, a DEM with $20 \mathrm{~m}$ resolution was used to perform the analysis.

The outcomes of this work are a valuable proof of the capability of PSI-based approach to selectively detect areas actually unstable especially if combined with in situ data, useful for cultural heritage applications. As a result, the implementation of PSI data in this work expands the current applications of PSI to landslides monitoring, by suggesting review of the pre-existing landslide inventory and consequently by demonstrating it to be potentially for supporting strategies of land planning and activities of built heritage management.

\section{Conclusions}

In this paper a multi-temporal landslide effects investigation was performed in San Fratello (Italy) chronically affected by landslide phenomena, in order to evaluate the ground motion impacts on the village, especially on the cultural heritage of the site. The analysis combines InSAR data, which maps the active slide movements over 20 years, with a reconnaissance of damage observed in built structures.

The most recent landslide phenomena in the San Fratello site occurred in 1922 and in February 2010, on the two opposite slopes on which the village is built.

The combined use of historical C-band from 1992 and new generation X-band SAR data up to 2012 permitted one to spatially and temporally detect and monitor ground deformations at a local scale, achieving a comprehensive detailed multi-temporal and spatial investigation of the village.

The InSAR results come from a dual persistent and distributed scatterer approach by means of SqueeSAR ${ }^{\mathrm{TM}}$ processing technique.

Persistent Scatterer Interferometry data were analyzed and combined with other available information on the test site, such as orthophotos and field survey observations carried out in March 2010 just after the 2010 phenomenon, and more recently in November 2012 and January 2013.

The obtained results allow improving the landslide inventory map of the area, properly providing an updated assessment of the instability on the study area. In particular, the outcomes of the work lead to proposed new boundaries of the landslide-affected areas in San Fratello village, not only for the 2010 landslide, where PSI data revealed four main unstable areas otherwise classified as stable, but also for the 1922 landslide, where a suspicious ground motion pattern was recognized by means of historical and recent PSI datasets up to 2010.

The cross-comparison of PSI data with local failures and damage of single edifices observed in situ allowed a validation of radar data, to finally achieve a complete analysis that can be particularly useful for strategies of cultural heritage and building management.

\section{Acknowledgments}

This work has been carried out in the framework of the DORIS project funded by the EC-GMES-FP7 initiative (Grant Agreement No. 242212). Persistent Scatterer Interferometry data were processed by TeleRilevamento Europa and were available within the DORIS project. Federico Di Traglia is supported by a post-doc fellowship founded by the Regione Toscana (UNIPI-FSE) under the project RADSAFE (UNIPI-4) in the framework of the research agreement between DST-UNIPI, DST-UNIFI and Ellegi s.r.l.-LiSALab. The authors would like to thank the Italian Civil Protection for field survey data collected after the 2010 landslide. Information on the cultural and historical heritage of San Fratello mostly derive from the websites of San Fratello village: http:// sottolapietra.blogspot.it/ and http://www.san-fratello. $\mathrm{com} /$.

Open Access This article is distributed under the terms of the Creative Commons Attribution License which permits any use, distribution, and reproduction in any medium, provided the original author(s) and the source are credited. 


\section{REFERENCES}

Adam, N., Eineder, M., Yague-Martinez, N., Bamler, R., High resolution interferometric stacking with TerraSAR-X, In Proc. of the Geoscience and Remote Sensing Symposium, IGARSS (Boston, MA, Jul. 7-11, 2008) pp. II-117-II-120.

AdB Regione Sicilia (2012), PAI - Piano Stralcio di Bacino per l'Assetto Idrogeologico, http://www.sitr.regione.sicilia.it/pai.

AleXANDer, D. (1989), Urban landslides. An International review of geographical work in the natural and environmental sciences, Progress in Phys Geography 13, 157-191.

Amodio-Morelli, L., Bonardi, G., Colonna, V., Dietrich, D., Giunta, G., Ippolito, F., Liguori, V., Lorenzoni, F., Paglionico, A., Perrone, V., Piccarreta, G., Russo, M., Scandone, P., ZanettinLorenzoni, E, Zuppetta, A. (1976), L'Arco Calabro-Peloritano nell'orogene appenninico-maghrebide, Mem Soc Geol It 17, 1-60.

Ardizzone, F., Basile, G., Cardinali, M., Casagli, N., Del Conte, S., Del Ventisette, C., Fiorucci, F., Garfagnoli, F., Gigli, G., Guzzetti, F., Iovine, G., Mondini, A. C., Moretti, S., Panebianco, M., Raspini, F., Reichenbach, P., Rossi, M., Tanteri, L., Terranova, O. (2012), Landslide inventory map for the Briga and the Giampilieri catchments, NE Sicily, Italy, J Maps, doi:10. 1080/17445647.2012.694271.

Bellotti, F., Bianchi, M., Colombo, D., Ferretti, A., Tamburini, A. (2014), Advanced InSAR Techniques to Support Landslide Monitoring. In Mathematics of Planet Earth, Lecture Notes in Earth System Sciences 2014, (ed. Springer Berlin Heidelberg), 287-290. doi:10.1007/978-3-642-32408-6_64.

Bianchini, S, Cigna, F, Righini, G, Proietti, C, Casagli, N (2012), Landslide HotSpot Mapping by means of Persistent Scatterer Interferometry, Environ Earth Sci 67(4), 1155-1172.

Bianchini, S., Herrera, G., Notti, D., Mateos, R.M., Garcia, I., Mora, O., Moretti, S. (2013), Landslide activity maps generation by means of Persistent Scatterer Interferometry, Remote Sens 5(12), 6198-6222.

Bianchini, S., Tapete, D., Ciampalini, A., Di Traglia, F., Del Ventisette, C., Moretti, S., Casagli, N. (2014), Multi-Temporal Evaluation of Landslide-Induced Movements and Damage Assessment in San Fratello (Italy) by Means of C- and X-Band PSI Data. In Mathematics of Planet Earth, Lecture Notes in Earth System Sciences, (ed. Springer Berlin Heidelberg), 257-261.

Bovenga, F., Wasowski, J., Nitti, D.O., Nutricato, R., Chiaradia, M.T. (2012), Using COSMO-SkyMed X-band and ENVISAT Cband SAR interferometry for landslides analysis, Remote Sens Environ, 119, 272-285.

Bru, G., Herrera, G., Tomás, R., Duro, J., De la Vega, R., Mulas, J. (2013), Control of deformation of buildings affected by subsidence using persistent scatterer interferometry, Struct Infrastruct Eng 9, 188-200.

Canuti, P., Casagli, N., Ermini, L., Fanti, R., Farina, P. (2004), Landslide activity as a geoindicator in Italy: significance and new perspectives from remote sensing, Environ Geol 45(7), 907-919.

Cascini, L., Fornaro, G., Peduto, D. (2009), Analysis at medium scale of low-resolution DInSAR data in slow-moving landslide affected areas, J Photogramm Remote Sens 64(6), 598-611.

Cascini, L., Fornaro, G., Peduto, D. (2010), Advanced low and full resolution DInSAR map generation for slow moving landslide analysis at different scales, Eng Geol 112, 29-42.
Ciampalini, A., Cigna, F., Del Ventisette, C., Moretti, S., Liguori, V., CASAGLI, N. (2012), Integrated geomorphological mapping in the north-western sector of Agrigento (Italy), J Maps 8(2), 136-145.

Cigna, F., Del Ventisette, C., Liguori, V., Casagli, N. (2011), Advanced radar-interpretation of InSAR time series for mapping and characterization of geological processes, Nat Haz Earth Sys Sci $11,865-881$.

Cigna, F., Del Ventisette, C., Gigli, G., Menna, F., Agili, F., Liguori, V., Casagli, N. (2012), Ground instability in the old town of Agrigento (Italy) depicted by on-site investigations and Persistent Scatterers data, Nat Haz Earth Sys Sci 12, 3589-3603.

Cigna, F., Bianchini, S., Casagli, N. (2013), How to assess landslide activity and intensity with Persistent Scatterer Interferometry (PSI): the PSI-based matrix approach, Landslides 10(3), 267-283.

Colesanti, C. and Wasowski, J. (2006), Investigating landslides with space-borne Synthetic Aperture Radar (SAR) Interferometry, Eng Geol 88, 173-199.

Corrado, S., Aldega, L., Balestrieri, M. L., Maniscalco, R., Grasso, M. (2009), Structural evolution of the sedimentary accretionary wedge of the alpine system in Eastern Sicily: Thermal and thermochronological constraints, Geol Soc Am Bull 121(11-12), 1475-1490.

Crosetto, M., Monserrat, O., Iglesias, R., \& Crippa, B. (2010), Persistent Scatterer Interferometry: potential, limits and initial $C$ - and $X$-band comparison, Photogramm Eng Remote Sens 76(9), 1061-1069.

Cruden, D.M., Varnes, D.J. (1996), Landslide types and processes. In, Landslides: Investigation an Mitigation: Sp. Rep. 247 eds. Turner, A.K. \& Schuster, R.L.), Transportation Research Board, National research Council, National Academy Press, Washington, DC, 36-75.

Cubito, A., Ferrara, V., Pappalardo, G. (2005), Landslide hazard in the Nebrodi Mountains (Northeastern Sicily), Geomorphology 66, (1-4), 359-372.

Cuevas, M., Crosetto, M., Monserrat, O., Monitoring urban deformation phenomena using satellite images, In 9th International Geomatic Week (Barcelona, Spain, 15-17 March 2011).

Del Ventisette, C., Garfagnoli, F., Ciampalini, A., Battistini, A., Gigli, G., Moretti, S., Casagli, N. (2012), An integrated approach to the study of catastrophic debris-flows: geological hazard and human influence, Nat Haz Earth Sys Sci 12, 2907-2922.

DIETRICH, D. (1988), Sense of overthrust shear in the Alpine nappes of Calabria (Southern Italy), J Struct Geol 10(4), 373-381.

Di Romolo, F., Lesioni degli edifici. Applicazioni di geotecnica e geofisica nell'analisi dei cedimenti delle fondazioni (Hoepli ed., Italy 2008).

D.R.P.C. - Dipartimento Regionale Protezione Civile - (2010), La frana di san Fratello (ME) del 14 febbraio 2010 - Relazione geologica e rapporto di sintesi sulle indagini geognostiche (Palermo, 2010).

Faranda, P., Città - giardino: il piano di Acquedolci. Storia e urbanistica di una città fondata in era fascista (1922-1932) (Qanat, Palermo, Italy 2010).

Farina, P., Colombo, D., Fumagalli, A., Marks, F., \& Moretti, S. (2006), Permanent Scatterers for landslide investigations: outcomes from the ESA-SLAM project, Eng. Geol. 88, 200-217.

Ferretti, A., Prati, C., Rocca, F. (2001), Permanent Scatterers in SAR Interferometry, IEEE Trans Geosci Remote Sens 39, 1, $8-20$. 
Ferretti, A., Prati, C., Rocca, F., Casagli, N., Farina, P., Young, B., Permanent Scatterers technology: a powerful state of the art tool for historic and future monitoring of landslides and other terrain instability phenomena, In Proc. of 2005 International Conference on Landslide Risk Management, (Vancouver, Canada, 2005).

Ferretti, A., Fumagalli, A., Novali, F., Prati, C., Rocca, F., RuccI, A. (2011), A new Algorithm for Processing Interferometric Data-Stacks: SqueeSAR, IEEE Transaction on Geo Sci Remote Sens 49(9), 3460-3470.

Frattini, P, Crosta, G.B., Allievi, J. (2013), Damage to Buildings in Large Slope Rock Instabilities Monitored with the PSInSAR ${ }^{T M}$ Technique, Remote Sens, Special issue: Remote Sensing for Landslides Investigation: From Research into Practice 5(10), 4753-4773.

Ge D., Wang Y., Zhang L., Guo X., and XIA Y., Mapping urban subsidence with TerraSAR-X data by PSI analysis, In Proc. of Geoscience and Remote Sensing Symposium (IGARSS), 2010 IEEE International, (Honolulu, Hawaii, USA, 2010) pp. 3323-3326.

Gernhardt, S., Adam, N., Eineder, M., Bamler, R. (2010), Potential of very high resolution SAR for Persistent Scatterer Interferometry in urban areas, Ann. GIS 16(2), pp. 103-111.

Grief, V., VLCKo, J. (2012), Monitoring of post-failure landslide deformation by the PS-InSAR technique at Lubietova in Central Slovakia. Environ Earth Sci 66(6), 1585-1595.

HARP E.L. (1998), Origin of fractures triggered by the earthquake in the Summit Ridge and Skyland Ridge areas and their relation to landslides, In The Loma Prieta, California, Earthquake of October 17, 1989-Landslides, (ed. Keefer D.K), U.S. Geological survey professional paper, pp. 1551-C.

Hanssen, R.F. (2005), Satellite radar interferometry for deformation monitoring: a priori assessment of feasibility and accuracy, Int J Appl Earth Obs 6, 253-260.

Herrera, G., Tomás, R., Monells, D., Centolanza G., Mallorqui J. J., Vicente, F., Navarro, V. D., Lopez-Sanchez, J. M., Cano, M., Mulas, J., Sanabria, M. (2010), Analysis of subsidence using TerraSAR-X data: Murcia case study, Eng. Geol 116, 284-295.

Herrera, G., Gutiérrez, F., Garcí-Davalillo, J.C., Guerrero, J., Galve, J.P., Fernández-Morodo, J.A., and Cooksley, G. (2013), Multi-sensor advanced DInSAR monitoring of very slow landslides: the Tena valley case study (central Spanish Pyrenees), Remote Sens Environ 128, 31-43.

Hooper, A. (2006), Persistent scatterer radar interferometry for crustal deformation studies and modeling of volcanic deformation, Ph.D. thesis, Stanford University.

KnotT, S.D. (1987), The Liguride Complex of Southern Italy-a Cretaceous to Paleogene accretionary wedge, Tectonophysics 142, 217-226.

Lavecchia, G., Ferrarini, F., de Nardis, R., Visini, F., Barbano, M.S. (2007), Active thrusting as possible seismogenic source in Sicily (Southern Italy): Some insights from integrated structuralkinematic and seismological data, Tectonophysics 445, 145-167.
Meisina, C., Notti, D., Zucca, F., Ceriani, M., Colombo, A., Poggi, F., Roccati, A., Zaccone, A., The use of PSInSAR ${ }^{\mathrm{TM}}$ and SqueeSAR ${ }^{\mathrm{TM}}$ techniques for updating landslide inventories, In Landslide Science and Practice, In Proc. of The Second World Landslide Forum, Volume 1: Landslide Inventory and Susceptibility and Hazard Zoning (eds. Margottini, C., Canuti, C., Sassa, K.) (Roma, Italy, 2013) pp. 81-88.

Mondini, A.C., Guzzetti, F., Reichenbach, P., Rossi, M., CardiNAli, M., Ardizzone, F. (2011), Semi-automatic recognition and mapping of rainfall induced shallow landslides using optical satellite images, Remote Sens Environ 115(7), 1743-1757.

Nigro, F. And Sulli, A. (1995), Plio-Pleistocene extensional tectonics in the Western Peloritani area and its offshore (northeastern Sicily), Tectonophysics 252, 295-305.

Notti, D., Davalillo, J.C., Herrera, G., Mora, O., (2010), Assessment of the performance of $X$-band satellite radar data for landslide mapping and monitoring: Upper Tena Valley case study, Nat Haz Earth Sys Sci 10, 1865-1875.

Ogniben, L., (1969), Nota illustrativa dello schema geologico della Sicilia nord-orientale, Riv Min Sicil 11, n. 64-65, 183-212.

Parcharidis, I., Foumelis, M., Pavlopoulos, K., Kourkouli, P.,Ground deformation monitoring in cultural heritage areas by time series SAR interferometry: the case of ancient Olympia site (Western Greece), In European Space Agency publications, Fringe Conference, ESA (Noordwijk, Holland, 2010).

Raspini, F., Moretti., S, Casagli, N., Landslide Mapping Using SqueeSAR Data: Giampilieri (Italy) Case Study, In Landslide Science and Practice, Proc. of The Second World Landslide Forum, Volume 1: Landslide Inventory and Susceptibility and Hazard Zoning (eds. Margottini, C., Canuti, C., Sassa, K.) (Roma, Italy 2013) pp. 147-154.

Righini, G., Pancioli, V., Casagli, N., (2012), Updating landslide inventory maps using Persistent Scatterer Interferometry(PSI), Int J Remote Sens 33(7), 2068-2096.

Roth, A.,TerraSAR-X: A new perspective for scientific use of high resolution spaceborne SAR data, In Proc. Of the2nd GRSS/ISPRS Joint workshop on remote sensing and data fusion on urban areas, (Berlin, Germany, 2003), pp. 4-7.

Tapete, D., Fanti, R., Cecchi, R., Petrangeli, P., Casagli, N. (2012), Satellite radar interferometry for monitoring and earlystage warning of structural instability in archaeological sites, $\mathrm{J}$ Geophys Eng 9, S10-S25.

Tomás, R., Herrera, G., Lopez-SAnchez, J.M., Vicente, F., Cuenca, A., Mallorquí J.J. (2010), Study of the land subsidence in the Orihuela city (SE Spain) using PSI data: distribution, evolution and correlation with conditioning and triggering factors, Eng Geol 115, 105-121.

VARNES, D. J., Slope movements, type and processes, In Landslide analysis and control. Transportation Research Board, National Academy of Sciences, (eds Schuster, R. L., Krizek, R. J.) (Washington, D.C., 1978), Special report 176, pp. 11-33. 